\title{
A plume-in-grid approach to characterize air quality impacts of aircraft emissions at the Hartsfield-Jackson Atlanta International Airport
}

\author{
J. Rissman ${ }^{1}$, S. Arunachalam ${ }^{2}$, M. Woody ${ }^{3}$, J. J. West $^{3}$, T. BenDor ${ }^{4}$, and F. S. Binkowski ${ }^{2}$ \\ ${ }^{1}$ Energy Innovation: Policy and Technology LLC, 98 Battery St. Ste. 202, San Francisco, CA 94111, USA \\ ${ }^{2}$ Institute for the Environment, University of North Carolina at Chapel Hill, Chapel Hill, NC 27599, USA \\ ${ }^{3}$ Department of Environmental Science and Engineering, University of North Carolina at Chapel Hill, Chapel Hill, \\ NC 27599, USA \\ ${ }^{4}$ Department of City and Regional Planning, University of North Carolina at Chapel Hill, Chapel Hill, NC 27599, USA
}

Correspondence to: S. Arunachalam (sarav@email.unc.edu)

Received: 13 November 2012 - Published in Atmos. Chem. Phys. Discuss.: 9 January 2013

Revised: 18 July 2013 - Accepted: 19 July 2013 - Published: 16 September 2013

\begin{abstract}
This study examined the impacts of aircraft emissions during the landing and takeoff cycle on $\mathrm{PM}_{2.5}$ concentrations during the months of June and July 2002 at the Hartsfield-Jackson Atlanta International Airport. Primary and secondary pollutants were modeled using the Advanced Modeling System for Transport, Emissions, Reactions, and Deposition of Atmospheric Matter (AMSTERDAM). AMSTERDAM is a modified version of the Community Multiscale Air Quality (CMAQ) model that incorporates a plumein-grid process to simulate emissions sources of interest at a finer scale than can be achieved using CMAQ's model grid. Three fundamental issues were investigated: the effects of aircraft on $\mathrm{PM}_{2.5}$ concentrations throughout northern Georgia, the differences resulting from use of AMSTERDAM's plume-in-grid process rather than a traditional CMAQ simulation, and the concentrations observed in aircraft plumes at subgrid scales. Comparison of model results with an air quality monitor located in the vicinity of the airport found that normalized mean bias ranges from $-77.5 \%$ to $6.2 \%$ and normalized mean error ranges from $40.4 \%$ to $77.5 \%$, varying by species. Aircraft influence average $\mathrm{PM}_{2.5}$ concentrations by up to $0.232 \mu \mathrm{g} \mathrm{m}^{-3}$ near the airport and by $0.001-0.007 \mu \mathrm{g} \mathrm{m}^{-3}$ throughout the Atlanta metro area. The plume-in-grid process increases concentrations of secondary PM pollutants by $0.005-0.020 \mu \mathrm{g} \mathrm{m}^{-3}$ (compared to the traditional grid-based treatment) but reduces the concentration of non-reactive primary PM pollutants by up to $0.010 \mu \mathrm{g} \mathrm{m}^{-3}$, with changes concentrated
\end{abstract}

near the airport. Examination of subgrid-scale results indicates that median aircraft contribution to grid cells is higher than median puff concentration in the airport's grid cell and outside of a $20 \mathrm{~km} \times 20 \mathrm{~km}$ square area centered on the airport, while in a $12 \mathrm{~km} \times 12 \mathrm{~km}$ square ring centered on the airport, puffs have median concentrations over an order of magnitude higher than aircraft contribution to the grid cells. Maximum puff impacts are seen within the $12 \mathrm{~km} \times 12 \mathrm{~km}$ ring, not in the airport's own grid cell, while maximum grid cell impacts occur within the airport's grid cell. Twenty-one (21) \% of all aircraft-related puffs from the Atlanta airport have at least $0.1 \mu \mathrm{g} \mathrm{m}^{-3} \mathrm{PM}_{2.5}$ concentrations. Near the airport, median daily puff concentrations vary between 0.017 and $0.134 \mu \mathrm{g} \mathrm{m}^{-3}$ (0.05 and $0.35 \mu \mathrm{g} \mathrm{m}^{-3}$ at ground level), while maximum daily puff concentrations vary between 6.1 and $42.1 \mu \mathrm{g} \mathrm{m}^{-3}$ (7.5 and $42.1 \mu \mathrm{g} \mathrm{m}^{-3}$ at ground level) during the 2-month period. In contrast, median daily aircraft contribution to grid concentrations varies between 0.015 and $0.091 \mu \mathrm{g} \mathrm{m}^{-3}$ (0.09 and $0.40 \mu \mathrm{g} \mathrm{m}^{-3}$ at ground level), while the maximum varies between 0.75 and $2.55 \mu \mathrm{g} \mathrm{m}^{-3}(0.75$ and $2.0 \mu \mathrm{g} \mathrm{m}^{-3}$ at ground level). Future researchers may consider using a plume-in-grid process, such as the one used here, to understand the impacts of aircraft emissions at other airports, for proposed future airports, for airport expansion projects under various future scenarios, and for other national-scale studies specifically when the maximum impacts at fine scales are of interest. 


\section{Introduction}

The Hartsfield-Jackson Atlanta International Airport is the busiest airport in the world in terms of passenger traffic (Airports Council International, 2010). Major airports such as Atlanta Hartsfield can be important economic drivers in their regions and key transit hubs for people worldwide. However, a large airport produces emissions that have the potential to adversely affect air quality in communities near the airport and throughout the wider region. Aircraft engines emit nitrogen oxides $\left(\mathrm{NO}_{\mathrm{x}}\right)$, sulfur dioxide, black carbon (soot), and other compounds that are primary air pollutants or contribute to formation of secondary pollutants through chemical reactions in the atmosphere.

In the past, numerical modeling of emissions along with atmospheric physical and chemical processes has been used to understand the air quality impacts of aircraft emissions. Fixed-grid (Eulerian) models are used to represent the effects of dispersed pollutant sources on air quality, but they lack the resolution to distinguish impacts near a major point source. Plume (Lagrangian) models represent pollutants as moving puffs to allow for better representation of impacts near a large point source and for chemical processing within a highly polluted plume. To gain the benefits of both techniques, plumein-grid models have been developed, which represent large point sources such as a single power plant or collection of power plants in their regional context (Karamchandani et al., 2002). Here we apply an Eulerian model with plume-in-grid capabilities to assess the effects of aircraft emissions on air quality near the airport and over a larger region. We represent airplane traffic from landing and takeoff as a series of emitters near the airport, the first application that we are aware of to use a plume-in-grid model to represent moving, elevated sources. (Kraabøl et al. $(2000,2002)$ used the results of a plume model to modify the production and loss terms for eleven compounds in grid cells corresponding to airplane flight paths in a gridded air quality model, but the two models were used in series and their approach greatly differed from the present study.)

We used the Advanced Modeling System for Transport, Emissions, Reactions, and Deposition of Atmospheric Matter, or AMSTERDAM (Karamchandani et al., 2010), to evaluate impacts of aircraft emissions during landing and takeoff (LTO) cycles $(<1000 \mathrm{~m})$ on ground-level pollutant concentrations during June and July 2002 at the Atlanta Hartsfield airport. Our study had three objectives. First, we aimed to characterize the effect of aircraft emissions at Hartsfield-Jackson airport on ground-level fine particulate matter $\left(\mathrm{PM}_{2.5}\right)$ concentrations in Atlanta and surrounding areas. Second, we set out to understand the differences in modeled $\mathrm{PM}_{2.5}$ concentrations resulting from the use of AMSTERDAM, which incorporates a plume-in-grid process for aviation emissions, relative to the use of a traditional gridded air quality model. Third, we compared the concentrations in aircraft plumes to the impacts of aircraft on grid cell con- centrations, to better understand whether localized very high concentrations may be obscured in an analysis that does not characterize subgrid-scale variability.

We examine total $\mathrm{PM}_{2.5}$ and its components (black carbon, sulfate, nitrate, ammonia, organic, and uncategorized $\mathrm{PM}_{2.5}$ ), because of the significant potential health impacts of fine particulate matter due to aviation (Levy et al., 2008, 2012; Arunachalam et al., 2011). Exposure to $\mathrm{PM}_{2.5}$ has been linked to increased rates of lung cancer and cardiopulmonary mortality (Pope et al., 2002).

Knowledge of aircraft contribution to pollutant concentrations is an important step in understanding the human and economic costs associated with aircraft-related pollution. Such analysis may also provide a useful baseline for comparison with scenarios that consider the efficacy of mitigation measures, such as use of biofuels, fuel-efficient engine technologies, altering airline flight schedules, and re-balancing load between different regional airports. Results may also be of interest to local governments siting new airports and planning land use near airports, and to regulators setting emissions standards for jet engines.

\section{Literature review}

\subsection{Model history and development}

Numerical modeling has been used to evaluate air quality impacts from aircraft activity at airports for decades. Two models commonly used to quantify aircraft emissions in the United States are the Emissions Dispersion and Modeling System (EDMS) (Federal Aviation Administration, 1998) and its successor, the Aviation Environmental Design Tool (AEDT) (Aviation Environmental Design Tool, 2010).

EDMS is the most commonly used aircraft emissions model in the US because the Federal Aviation Administration (FAA) designated it in 1998 as the required model for air quality analyses of aviation emissions sources. EDMS calculates aviation emissions during the LTO cycle within the mixing height. Researchers have used EDMS to address topics that relate to local air quality impacts, such as the effects of a reduction in aircraft thrust at takeoff on annual $\mathrm{NO}_{\mathrm{x}}$ emissions (Hall, 2003) and the air quality impact of new construction projects at airports (Moss, 1994).

The FAA is currently developing the AEDT, a model that estimates aircraft emissions, noise, and other impacts. Similar to EDMS, AEDT calculates aircraft flight performance and uses this information to generate emissions. Preliminary versions of this model have been used by researchers (Noel, 2009; Wilkerson, 2010). EDMS generates outputs at an airport level, while AEDT generates outputs from airport level to national to global scales. EDMS and AEDT outputs can be used in dispersion models, such as the American Meteorological Society/US EPA Regulatory Model (AERMOD) 
(Cimorelli et al., 2005) and other chemistry transport models as discussed below.

AMSTERDAM takes emissions and meteorological information as inputs, and it simulates chemistry and physical processes associated with emissions sources at subgrid-scales to determine the resulting environmental concentrations. As AMSTERDAM was built from a combination of two earlier models, we first discuss each component model. The first component is the Community Multiscale Air Quality modeling system (CMAQ) (Byun and Schere, 2006). CMAQ is an Eulerian model based on a 3-D grid. It accepts meteorology and emissions inputs, models chemical and microphysical processes, and determines the resulting chemical concentrations in each grid cell. CMAQ has been used in the past to model the impacts of aviation emissions (Unal et al., 2005; Arunachalam et al., 2008, 2011; Ratliff et al., 2009; Woody et al., 2011). However, CMAQ is limited by its reliance on grid cells that are relatively large in size and may not accurately represent the chemical processes in concentrated emissions plumes, such as those emitted by aircraft. Understanding these processes is critical for local-scale air quality assessment in and around an airport. Large grid cells may result in an artificial dilution of emissions, which can alter the chemical reactions that form pollutants and can result in over- or under-prediction of pollutant concentrations near emissions sources (Arunachalam et al., 2008).

The second component is the Second-order Closure Integrated puff model with CHEMistry (SCICHEM), which evolved from a model called "SCIPUFF". SCIPUFF is a Lagrangian dispersion model originally developed to model the fate and transport of hazardous materials (Sykes and Gabruk, 1997; Sykes et al., 1998). It tracks emissions as a series of individual "puffs" in three-dimensional space. SCIPUFF focuses on modeling the locations and sizes of emitted puffs, accounting for physical factors such as winds and buoyancy. It is capable of dividing puffs that become too large into smaller puffs and merging overlapping puffs together (Karamchandani et al., 2010). SCIPUFF was later extended with the capability to utilize chemistry routines to account for reactions occurring inside the puffs and renamed "SCICHEM" (Santos et al., 2000). SCICHEM supports both intraplume and inter-plume interactions by treating both splitting and merging of puffs to account for wind shear effects and varying chemistry across the plume. SCIPUFF and SCICHEM have been used in numerous research studies of plume dispersion, specifically from major point sources such as power plants, but they have seldom if ever been used to model aviation emissions.

Finally, we review the development history behind AMSTERDAM. Karamchandani et al. (2002) created an air quality model by combining CMAQ and SCICHEM. Karamchandani et al. (2002) named their model "CMAQ-APT", wherein "APT" stands for "advanced plume treatment", referring to the capabilities added by SCICHEM. In this model, emissions that are not of direct interest are added directly to the grid, as in a traditional CMAQ model simulation. Emissions from sources of interest are represented as Gaussian puffs, which are tracked separately in three-dimensional space within the CMAQ grid. The combination of these two approaches is called plume-in-grid (PinG). In CMAQ-APT, the same chemistry routines are used to model reactions within the puffs as well as within each grid cell. As puffs age, they grow larger and more dilute due to infiltration of background air. When puffs are sufficiently large, AMSTERDAM no longer tracks them separately from the surrounding air. AMSTERDAM makes this determination by using one of two physical criteria. The primary criterion is met if the horizontal size of the puff accounting for spread in both the $x$ and $y$ directions is equal to the grid cell size. The secondary criterion is met when the horizontal size in any one direction is 16 times the grid cell size in the same direction. For most applications, the dumping occurs based upon the first criterion, and the second criterion was implemented to address elongated puffs that would otherwise get transported to longer distances leading to instability in the model. When either criterion is met, the puffs' contents are added to the grid cells where the puffs are located (based upon the centroid of the puffs), and the puffs themselves are removed from the model. Thus, in each timestep, new puffs are added to the simulation while old puffs are "merged" into the grid.

Karamchandani et al. (2006) then enabled their model to utilize a different mechanism for simulation of particulate matter: the Model of Aerosol Dynamics, Reaction, Ionization, and Dissolution (MADRID), whose most important changes related to the model's particle size distribution and secondary organic aerosol formation. By 2008 , they produced a version with new mercury- and aerosol-related processes called the "Advanced Modeling System for Transport Emissions, Reactions and Deposition of Atmospheric Matter" (AMSTERDAM), whose impacts on mercury results were examined by Vijayaraghavan et al. (2008). In a later paper, the same team describes AMSTERDAM as a "suite" of three models: CMAQ-AERO3-APT (which uses the original CMAQ particulate matter treatment plus SCICHEM PinG), CMAQ-MADRID (which uses the MADRID particulate matter treatment without PinG), and CMAQ-MADRIDAPT (which uses both the MADRID PM treatment and SCICHEM PinG) (Karamchandani et al., 2010). In our study, we used only the first of these model configurations, i.e. the version that combines CMAQ and APT. Additional details about this model and its configuration options are available in Karamchandani et al. (2010). An updated version of the APT module has been implemented in the latest release of CMAQ v5.0 (with several updates to the overall modeling system, including an enhanced aerosol module AERO6), and it is expected to be publicly available later this year. 


\subsection{Prior model applications for Hartsfield-Jackson International Airport}

This study extends prior modeling work that has been conducted to understand the impacts of aircraft emissions at the Hartsfield-Jackson Atlanta International Airport. Unal et al. (2005) modeled aircraft emissions during a high-pollution episode from 11 to 20 August 2000 using CMAQ. For PM 2.5 emissions, they relied on a first-order approximation by Wayson et al. (2003), which is a predecessor to the method used in this study (Wayson et al., 2009). Using emissions differentiated by flight mode and added to the model in 3-D space based on aircraft flight paths, they found the airport had a maximum impact on $\mathrm{PM}_{2.5}$ levels of $4.4 \mu \mathrm{g} \mathrm{m}^{-3}$ and impacts of about $1 \mu \mathrm{g} \mathrm{m}^{-3}$ in a radius of $16 \mathrm{~km}$ around the airport.

In order to enable the airport to be efficiently examined with the CMAQ model, Baek et al. (2007) developed a tool, "EDMS2Inv", which is capable of converting the emissions files created by EDMS (intended for use in AERMOD) into a format that allows them to be used in CMAQ. This tool was used to conduct an analysis of the impacts of LTO emissions at three airports: Providence T. F. Green (PVD), Chicago O'Hare (ORD) and Atlanta HartsfieldJackson (ATL) (Arunachalam et al., 2008). In that study, annual and monthly average aircraft contribution to $\mathrm{PM}_{2.5}$ and its components were modeled at CMAQ grid resolutions of $12 \mathrm{~km}$ and $36 \mathrm{~km}$. Arunachalam et al. (2008) found that in the grid cell with the maximum impact due to aircraft at the $12 \mathrm{~km}$ resolution, annual average $\mathrm{PM}_{2.5}$ concentrations increased by over $0.2 \mu \mathrm{g} \mathrm{m}^{-3}$.

A study estimating mortality due to $\mathrm{PM}_{2.5}$ exposure from LTO emissions at three airports (ATL, ORD, and PVD) used emissions derived from EDMS in CMAQ simulations (Arunachalam et al., 2011). ATL was investigated at $36 \mathrm{~km}$, $12 \mathrm{~km}$, and $4 \mathrm{~km}$ grid resolutions. The run with $4 \mathrm{~km}$ resolution included June and July 2002 and used the same background (i.e., non-aviation) emissions as the present study. They reported that the monthly average $\mathrm{PM}_{2.5}$ contribution due to ATL airport emissions at the grid cell containing the airport ranged from slightly below 0.1 to $0.65 \mu \mathrm{g} \mathrm{m}^{-3}$ depending on modeled grid resolution. The study concluded that a lower-resolution model with large domain is suitable for understanding population-average exposure, but an assessment of maximum individual risk would require highresolution modeling near the airport.

Woody and Arunachalam (2013) extended the work by Arunachalam et al. (2011) and investigated the effects of aircraft emissions on secondary organic aerosol (SOA) formation near Hartsfield-Jackson International Airport, by using an instrumented version of CMAQ with the process analysis tool. They used EDMS emissions processed through the EDMS2Inv tool as input data for CMAQ model runs at $36 \mathrm{~km}, 12 \mathrm{~km}$, and $4 \mathrm{~km}$ grid resolutions. Woody and Arunachalam found that in the grid cell containing the air- port at the $36 \mathrm{~km}$ and $12 \mathrm{~km}$ resolutions, aircraft reduced anthropogenic and biogenic SOA concentrations by up to $6.2 \%$ $\left(0.052 \mu \mathrm{g} \mathrm{m}^{-3}\right)$ by removing nitrate, hydroxyl, and hydroperoxy radicals through chemistry, leaving fewer nitrate radicals to oxidize SOA precursors. However, at the $4 \mathrm{~km}$ grid resolution, aircraft emissions increased SOA concentrations (primarily due to changes in biogenic SOA) by up to $11.5 \%$ $\left(0.081 \mu \mathrm{g} \mathrm{m}^{-3}\right)$ due to primary organic aerosol (POA) emissions from aircraft, with the additional organic mass shifting partitioning of SOA semi-volatile gas-phase species into the particle phase. The use of larger grid cells diluted POA concentrations, lowering SOA production in those model runs.

\subsection{Notable related modeling work}

Plume modeling of aircraft impacts is an area of active research, and a number of scientists are using related approaches to understand the environmental consequences of aviation emissions. For example, Naiman et al. (2010) developed a subgrid plume model (SPM) and used it to track aircraft emissions by modeling linear aircraft contrails. Naiman et al. (2010) suggest that their model is computationally efficient and, in the future, could be used as a subgrid process in a large-scale atmospheric simulation. Meilinger et al. (2005) note the difficulty of accounting for the chemistry and microphysics of aircraft exhaust in chemistry transport models due to their coarse grids. They present a model in which background photochemistry and chemical and physical plume processes are handled in separate "boxes", with mixing between the two. Wong et al. (2008) are also developing a model, the Aerosol Dynamics Simulation Code (ADSC), to calculate plume chemistry, dilution, and microphysics of aircraft plumes. Their inputs are based on several measurement campaigns (Herndon et al., 2008; Timko et al., 2010). Although Wong's model is not yet ready to be employed as a subgrid process within a gridded air quality model due to long computational times, we are aware of ongoing work to parameterize those outputs and use them as inputs to CMAQ.

\section{Modeling approach}

We completed three model simulations, or "test cases", using a modified version of the CMAQ-AERO3-APT model from AMSTERDAM. This configuration is based on CMAQ v4.6, uses the Carbon Bond IV (CB-IV) chemical mechanism for gas-phase chemistry, and uses the AERO3 module for aerosol treatment. All test cases used a $504 \mathrm{~km} \times 408 \mathrm{~km}$ domain with $4 \mathrm{~km}$ grid cell resolution centered on the Atlanta airport. The model used 19 vertical layers from the surface to $100 \mathrm{mb}$ (about $15 \mathrm{~km}$ ) whose thickness increased with altitude. Air quality was modeled for June and July 2002 (plus an 11-day spin-up period in May). The initial and boundary 
conditions were extracted from another regional-scale simulation at $12 \mathrm{~km}$ resolution for the same period.

Meteorology inputs for 2002 were based upon the Pennsylvania State University/NCAR Mesoscale Model (MM5) (Grell et al., 1994). Each test case used background (nonaviation) emissions based on the National Emissions Inventory (NEI) for 2002 produced by the US Environmental Protection Agency (US EPA, 2013a) and processed through the Sparse Matrix Operator Kernel Emissions (SMOKE) model (Houyoux et al., 2000).

Test case 1 (TC1) included aviation emissions within the LTO cycle modeled using the PinG process built into AMSTERDAM. Test case 2 (TC2) omitted aviation emissions. Test case 3 (TC3) included aviation emissions but avoided use of PinG by adding those emissions to the CMAQ grid directly. The emissions are identical in quantity and chemical composition to those in $\mathrm{TC} 1$.

In TC1 and TC3, we use engine data from the International Civil Aviation Organization (ICAO, 2010) and a methodology developed by Wayson et al. (2009) to estimate sulfate, organic $\mathrm{PM}_{2.5}$, and black carbon aviation emissions. This methodology, known as FOA3.0 (version 3.0 of a first-order approximation), is also used in the EDMS and AEDT models. It is based on a statistical correlation between smoke number (a metric based on the coloration of soot from a particular engine) and available data on PM emissions by engine. The process used to calculate aviation emissions at each timestep is detailed in the next section.

Our study attempts to build on prior work in a number of ways. This is the first time that a plume-in-grid model has been used to characterize airport-related aviation emissions in the context of a regional air quality model with chemistry (CMAQ). EDMS and AERMOD, the most commonly used models in the past, do not adequately represent the chemical processes occurring in the aircraft plume and have not been as effective as a detailed chemistry-transport model such as CMAQ at predicting aircraft impacts on primary and secondary pollutants at large distances from the airport.

In addition, this is the first use of AMSTERDAM in which multiple emitters have been used to represent emissions from a large number of individual points (aircraft engines) that vary in space and time. In the past, AMSTERDAM has primarily been used to study emissions from power plants (Karamchandani et al., 2006; Vijayaraghavan et al., 2008). These large sources were widely spread across the country, and a single Gaussian puff emitter represented each source. More recently, AMSTERDAM was also used to study toxic air pollutants from highway mobile sources in New York City (Karamchandani et al., 2009). In this study, we used 51 distinct emitters to represent activity in the immediate geographic vicinity of the airport, and emitters were divided into four types based on the mode of flight they represented (taxi, takeoff, climb-out, and approach). By using many emitters in close proximity to one another with differing emissions profiles, we gain finer control over the location and characteristics of the emissions input to the model.

Third, this work does not use a preexisting emissions inventory for Hartsfield-Jackson generated by EDMS. Rather, we calculate aircraft emissions in each timestep using a detailed understanding of the characteristics of the individual aircraft engines used at Hartsfield-Jackson Airport, as well as the number of flights that occurred in each hour of the modeling period. This method is described in detail below, and the resulting emissions totals are compared to the EDMS-derived values used in prior work (Arunachalam et al., 2008, 2011).

\section{Calculating aviation emissions}

In order to model air quality impacts from the Atlanta International Airport, it was necessary to represent aircraft emissions during LTO activity as a number of point source emitters. This involves two steps: determining the quantities of different pollutants that are emitted at each timestep and positioning the emitters in 3-D space. These steps are discussed in the next two subsections.

\subsection{Quantifying emissions by timestep}

In this project, we model LTO emissions up to $1000 \mathrm{~m}$ above the ground. Emissions in this altitude range are the result of four activities: taxi (or idle) emissions which occur on the ground, takeoff emissions which occur from zero to $304 \mathrm{~m}$ for departing planes, climb-out emissions which occur from 304 to $1000 \mathrm{~m}$ for departing planes, and approach emissions from 1000 to $0 \mathrm{~m}$ for arriving planes (Rice, 2003).

Emissions above $1000 \mathrm{~m}$, including all cruise emissions, are omitted from the model runs to focus on the effect of LTO emissions at ATL on surface air quality. Furthermore, cruise emissions would be associated with aircraft from many airports. Omitting emissions above this altitude may lead to an underestimation of overall aircraft impacts on surface air quality, particularly in grid cells that are not near the airport and along flight corridors. Three recent studies have quantified this impact using global-scale models (Barrett et al., 2010; Whitt et al., 2011; Lee et al., 2013).

We performed our own emissions calculation based on the physical characteristics of each engine model when operating in each mode of flight. We use 2005 arrival and departure data to represent the number of flights using each engine at Hartsfield-Jackson in 2002 (the year represented by our other inputs, such as meteorology and background emissions) because a detailed breakdown of how many flights used each model of engine was not available for 2002. In 2005, Hartsfield-Jackson Airport had 972248 aircraft movements, an increase of $9.2 \%$ over the 889966 aircraft movements in 2002 (Airports Council International, 2013), so our 
results may show $\mathrm{PM}_{2.5}$ impacts slightly higher than would be expected if 2002 flight data had been available.

Aircraft engines have different emissions characteristics depending on their power setting. Key properties that change with power setting include fuel flow rate, smoke number (a metric based on the coloration of emitted soot), and emissions indices (mass ratios of pollutant emitted to fuel burned) for various pollutants. Therefore, in order to determine the total amount of each pollutant emitted by aircraft during 2005, it is necessary to total the emissions from each model of engine from each phase of the LTO cycle. This was done according to Eq. (1) for each chemical species:

$$
\begin{aligned}
& \sum_{1}^{N_{\text {models }}} 2 F_{\text {engine }}\left(\left(T_{\text {takeoff }} \cdot E_{\text {takeoff }}\right)+\left(T_{\text {climbout }} \cdot E_{\text {climbout }}\right)\right. \\
& \left.+\left(T_{\text {approach }} \cdot E_{\text {approach }}\right)+\left(T_{\text {taxi }} \cdot E_{\text {taxi }}\right)\right) .
\end{aligned}
$$

In Eq. (1), $F_{\text {engine }}$ refers to the number of flights using that engine model in 2005. $N_{\text {models }}$ is the number of engine models used to generate emissions inputs. $T_{\text {mode }}$ is time-in-mode, the average time aircraft spend in that particular mode of flight. $E_{\text {mode }}$ refers to the emissions rate of a pollutant (in $\mathrm{g}$ or $\mathrm{mol} / \mathrm{s}$ ) for that particular engine model in that flight mode. The coefficient 2 is present because we assume that there are two engines per aircraft. Thus, we sum the emissions from every engine in each mode to estimate the total emissions for each pollutant.

The values of $F_{\text {engine }}$ for each engine model are the same as those used in Arunachalam et al. (2011) and were based upon previous environmental impact studies. For time-inmode values, we chose to use the reference values recommended for gaseous emissions calculations by the International Civil Aviation Organization (ICAO, 1993): $0.7 \mathrm{~min}$ for takeoff, $2.2 \mathrm{~min}$ for climb-out, and $4.0 \mathrm{~min}$ for the approach. Although the accuracy of these values for modern jet aircraft has been questioned (Rice, 2003), we felt there were no more accurate, authoritative values available. We chose to use an average value for taxi mode specific to the Atlanta International Airport in 2005 of $27.22 \mathrm{~min}$ (consistent with the approach used in Arunachalam et al., 2008, 2011), rather than ICAO's reference value of $26.0 \mathrm{~min}$.

Key engine characteristics necessary to calculate emissions rates were obtained from ICAO's engine databank (2010). The engine databank provided fuel flow rates $\left(\mathrm{kg} \mathrm{s}^{-1}\right)$, engine type (single or multiple turbofan), bypass ratio (ratio of air drawn through the periphery of the engine to air drawn through the core), smoke numbers, and emissions indices for hydrocarbons, carbon monoxide, and $\mathrm{NO}_{\mathrm{x}}$. When an engine did not have mode-specific smoke number data available in the ICAO databank, a revised version of the Calvert method (Eyers, 2007) (which provides factors by which takeoff smoke numbers may be multiplied to obtain mode-specific smoke numbers for various engine classes) was used to calculate mode-specific smoke numbers.
Emission indices for $\mathrm{SO}_{2}, \mathrm{H}_{2} \mathrm{SO}_{4}$, organic $\mathrm{PM}$, and elemental carbon (also called black carbon or soot) were obtained via the methodologies described by Wayson et al. (2009). However, for values related to sulfur, we used numbers suggested by the FAA for use in the AEDT model. In particular, we assume that $2 \%$ of emitted sulfur is $\mathrm{S}(\mathrm{VI})$ rather than S(IV), and we use a sulfur fuel content of $600 \mathrm{ppm}$. The ICAO engine databank provides a hydrocarbon emissions index, which we multiply by 1.16 to obtain the total organic gas (TOG) emissions index. The engine databank also provides a total $\mathrm{NO}_{\mathrm{x}}$ emissions index, which we speciate as $76 \% \mathrm{NO}, 23 \% \mathrm{NO}_{2}$, and $1 \% \mathrm{HONO}$ (Wood et al., 2008).

To be represented in the model, TOG must be further speciated into its component parts. We used a breakdown of TOG components from a joint FAA/EPA document describing best practices for quantifying organic gas emissions from aircraft engines (FAA and EPA, 2009). This document is based upon a series of recent aircraft measurement campaigns and is a substantial update to the previous approach developed by Spicer et al. (1994), which has been used in the literature for speciating aircraft-emitted TOG to date. The new approach divided TOG into 77 explicit organic compounds and 4 categories of unknown compounds. These species were then mapped onto the 8 compounds that represent TOG in AMSTERDAM's chemical mechanism (a modified version of Carbon Bond IV), using ratios provided by the US EPA's SPECIATE tool (US EPA, 2013b).

Emissions were calculated for the 17 most commonly used engines at Hartsfield-Jackson. This encompassed $96.5 \%$ of the total aircraft activity at the airport. The remaining $3.5 \%$ of activity was represented as a weighted average of the top 17 engines. Using this process, we obtained total annual emissions values for $\mathrm{CO}, \mathrm{NO}, \mathrm{NO}_{2}, \mathrm{HONO}, \mathrm{H}_{2} \mathrm{SO}_{4}, \mathrm{SO}_{2}$, organic PM, elemental carbon, and eight volatile organic compound (VOC) species in each of the four flight modes. The eight representative VOC species as defined in CB-IV (Gery et al., 1989) are PAR for paraffins, OLE for olefins, TOL for toluene and other monoalkyl aromatics, XYL for xylene and other polyalkyl aromatics, FORM for formaldehyde, ALD2 for higher aldehydes, ETH for ethene, and ISPD for isoprene products.

We assumed that the relative use of different engine models was constant throughout the year, so the emissions in each one-hour timestep were directly proportional to total aircraft activity in that timestep. Information on the relative frequency of flights in each month of the year, day of the week, and hour of the day at Atlanta International Airport was based upon previously generated emission inventories for Atlanta used by Arunachalam et al. $(2008,2011)$. We used these activity ratios and the total annual emissions for each flight mode to calculate timestep-specific emissions for each flight mode. Each mode's emissions were divided evenly among the emitters we defined for that mode in every timestep. 


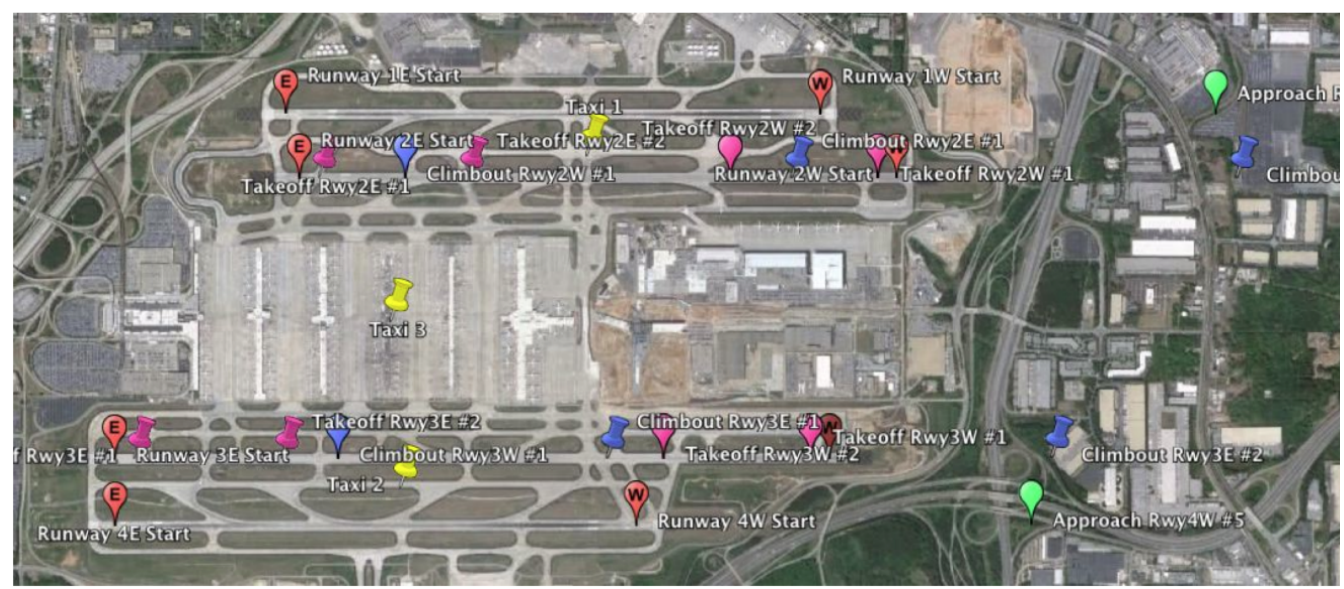

Fig. 1. Hartsfield-Jackson Atlanta International Airport with a subset of emitters as represented in Google Earth. Yellow = taxi mode emitter, pink $=$ takeoff mode emitter, blue = climb-out mode emitter, green = approach mode emitter. Red "E" and "W" markers are reference points at the ends of the runways relative to which emitters are placed.

\subsection{Placing emitters to represent air traffic}

In AMSTERDAM, the number and locations of emitters in 3-D space cannot be changed over the course of a model run. Therefore, it was necessary to determine a static arrangement of emitters that would best represent the totality of aviation emissions from the airport. Hartsfield-Jackson Atlanta Airport has five runways, all oriented in the east-west direction and ranging from 2740 to $3624 \mathrm{~m}$ in length. However, in the model year (2002), the southernmost runway was not yet operational. Of the remaining four runways, the outer two are used for arriving planes, while the inner two are used for departures. At any given time, landings and takeoffs are conducted either from west to east or from east to west depending on the prevailing winds. A study analyzing flight operations in 1998-1999 found that the two directions were used with approximately equal frequency (Gladstone, 2000). We assume both directions of operation were equally frequent during our modeling period, so emissions are divided evenly between the two directions.

A total of 51 emitters were used in the model. These emitters were divided into four modes: takeoff, climb-out, approach, and taxi. For each departure runway and each direction, two emitters were used to produce takeoff mode emissions and five emitters for the climb-out mode emissions. For each arrival runway, five emitters were used to produce approach emissions in each direction. Three emitters were used to produce taxi emissions: one near the taxiways for each pair of runways and one near the gates (Fig. 1), with taxi mode emissions divided evenly between them. Please see the Supplement for a file ("ATL_Emitters_GoogleEarth.kmz") that allows the emitters to be explored interactively in 3-D space using the Google Earth software program. The emitters along the westbound departure path from the northern runway are connected with green lines to assist in visualizing how emitters are positioned to follow a flight path.

Within each flight mode, each emitter receives an equal share of that mode's emissions in each timestep, so we place emitters so as to most evenly cover the space in which aircraft operate in each mode, taking into account the fact that accelerating or decelerating aircraft spend more time in one part of that space than another. Aircraft were assumed to have constant acceleration and deceleration during each mode of flight, with planes in takeoff mode going from 0 to $225 \mathrm{ft} \mathrm{s}^{-1}$, climb-out from 225 to $422 \mathrm{ft} \mathrm{s}^{-1}$, and approach mode decelerating from 422 to $250 \mathrm{ft} \mathrm{s}^{-1}$. These speeds were estimated based on statistics for several aircraft models (Air New Zealand, 2013) and consultation with the FAA. These speeds were used in conjunction with ICAO's time-in-mode estimates to determine the linear distance traveled by aircraft in each mode (ICAO, 1993). Aircraft were assumed not to turn or change heading within the lowest $1000 \mathrm{~m}$ of altitude, the region included in this study. The distance covered by aircraft in each flight mode was divided into segments that represent equal time intervals rather than equal lengths (so that mode-specific emissions would be equal in each segment). An emitter was positioned at the time-based center of each segment (i.e., the location a plane would be once half of the time that plane spent in a segment had elapsed). The path of travel in each flight mode was assumed to be linear, except for the takeoff mode, wherein the first segment was assumed to be along the runway and the entire altitude gain was included in the second segment.

Using these assumptions, the horizontal and vertical position of each emitter was calculated. Google Earth was used to position emitters relative to the airport runways and to obtain latitude and longitude coordinates for each emitter. Ultimately, climb-out emitters spanned six grid cells $(24 \mathrm{~km})$ in the east-west direction, and approach emitters spanned 
Table 1. Comparison of total annual aircraft emissions (in $\mathrm{kg}$ ) from the Atlanta airport at altitudes below $1000 \mathrm{~m}$ for TC1- and EDMSderived emissions used in Arunachalam et al. (2008, 2011).

\begin{tabular}{lrrc}
\hline Species & $\mathrm{TC} 1$ & EDMS & EDMS/TC1 \\
\hline $\mathrm{CO}$ & 3923571 & 4963366 & $127 \%$ \\
$\mathrm{NO}_{\mathrm{x}}$ (as $\mathrm{NO}_{2}$-eq) & 4458035 & 4223206 & $95 \%$ \\
$\mathrm{SO}_{2}$ TOG* $^{*}$ as $\mathrm{CH}(1.85)$-eq] & 454324 & 515342 & $113 \%$ \\
$\mathrm{PAR}$ & 351081 & 590607 & $168 \%$ \\
$\mathrm{OLE}$ & 130761 & & \\
$\mathrm{TOL}$ & 26979 & & \\
$\mathrm{XYL}$ & 7488 & & \\
FORM & 8664 & & \\
$\mathrm{ALD} 2$ & 48920 & & \\
ETH & 51215 & & \\
ISPD & 54171 & & \\
Sulfate PM (PSO4) & 1506 & & \\
Org PM (POA) & 14198 & 39456 & $278 \%$ \\
EC (PEC) & 3318 & 19271 & $581 \%$ \\
\hline
\end{tabular}

* Excludes unburned hydrocarbons from aircraft startup activities, whereas previously reported EDMS TOG values in Arunachalam et al. $(2008,2011)$ included them.

twelve grid cells $(48 \mathrm{~km})$ in the east-west direction. Vertically, emitters spanned the lowest 11 layers (up to about $1 \mathrm{~km}$ ) of the 19-layer modeling domain.

\subsection{Comparison of aviation emissions}

Table 1 compares the total annual emissions of several species used in TC1, and the emissions totals below $1000 \mathrm{~m}$ produced by EDMS, which was used in past work such as that by Arunachalam et al. $(2008,2011)$ and Woody and Arunachalam (2013). The emissions used in this study were less than the emissions calculated by EDMS for all species except $\mathrm{NO}_{\mathrm{x}}$. For primary elemental carbon (PEC), the nonvolatile component of PM, both studies used FOA3 and the numbers are closer to each other. For the other two PM species such as Primary Organic Aerosol (POA) and Primary Sulfate (PSO4) (both of which are considered as volatile PM components), differences are attributed to the use of FOA3a for EDMS emission estimates versus FOA3 in this study. The determination of fine particulate matter emissions from aircraft engines is an active area of research due to limited test data, and test methods are still under development and refinement. Subsequent to the completion of the development of FOA3 for ICAO, the methodology was modified with margins to conservatively account for the potential effects of uncertainties that include the lack of a standard test procedure, poor definition of volatile PM formation in the aircraft plume, and the limited amount of data available on aircraft PM emissions. This modified methodology is known as FOA3a, and was used to study air quality impacts from aircraft emissions on a national scale in the US (Ratliff et al., 2009). Since FOA3a is meant to represent the upper bound of PM emission estimates, one would therefore expect volatile PM emissions estimated by EDMS to be higher. In fact, Ratliff et al. note that the volatile PM inventories predicted by FOA3a for some aircraft engines are approximately 5 times those predicted by FOA3, and this factor of 5 between FOA3a and FOA3 - the official method approved by ICAO - reflects the scientific uncertainty associated with PM emissions from aircraft engines. For TOG, EDMS emissions include startup activities for aircraft, which were omitted in this study due to limited data available from ICAO on startup emissions indices and fuel burn. For gas-phase species as well as PM, the application of the emission profile for the most common engines across all engines at Atlanta may also lead to differences in emissions. It is plausible that the (less commonly used) $3.5 \%$ of engines for which we did not explicitly calculate emissions are older engines, and therefore they are responsible for a disproportionate amount of emissions compared to the more commonly used engines.

\section{Results and analysis}

\subsection{Model performance}

Model performance was evaluated by comparing our results to measurements from the Chemical Speciation Network (CSN), which reports results as a $24 \mathrm{~h}$ average every third day. Within our modeling domain, there were $11 \mathrm{CSN}$ monitors (Fig. 2). Results from TC1 were compared with all of these CSN monitors. Concentrations, normalized mean error and normalized mean bias averaged across the model run are reported in Table 2. Since most of these monitors are far from the airport, results in Table 2 reflect the performance of the model as a whole, rather than the error and bias of airportspecific impacts.

Table 3 shows results from all three test cases compared with the single monitor closest to the airport in Decatur (monitor number 130890002), located $11.2 \mathrm{~km}$ northeast of the airport's edge. All three test cases produced mean results that match to within a few hundredths of $\mathrm{ag} \mathrm{m}^{-3}$, and normalized mean error and bias typically vary by no more than $1 \%$ between the test cases. Notably, the differences between TC1 (the base case) and TC3 (the case without the PinG process) are too small to draw meaningful conclusions about whether the PinG process increases or decreases model accuracy or precision. The two pollutants with the most underprediction are secondary organic aerosol (OC) and sulfate aerosol $\left(\mathrm{SO}_{4}\right)$. Small improvements in model performance among the test cases do not necessarily imply more accurate methods of modeling aircraft, as the uncertainty in all model simulations is relatively large. However, the PinG approach helps us with an enhanced characterization of subgrid-scale variability, as we will illustrate later.

For the base test case (TC1), the model predicted twomonth average $\mathrm{PM}_{2.5}$ concentrations from 10 to $12.2 \mu \mathrm{g} \mathrm{m}^{-3}$ 
Table 2. Comparison of TC1 model results (in $\mu \mathrm{g} \mathrm{m}^{-3}$ ) to monitor observations from the 11 CSN monitors (see locations of these monitors in Fig. 2) in June and July 2002.

\begin{tabular}{lrccc}
\hline & TC1 mean & observed mean & norm mean error & norm mean bias \\
\hline Nitrate Aerosol & 0.291 & 0.581 & $78.2 \%$ & $-49.8 \%$ \\
Sulfate Aerosol & 3.083 & 6.000 & $49.4 \%$ & $-48.6 \%$ \\
Ammonium Aerosol & 1.066 & 1.649 & $44.1 \%$ & $-35.4 \%$ \\
EC & 0.509 & 0.724 & $50.4 \%$ & $-29.7 \%$ \\
OC & 0.933 & 4.926 & $81.1 \%$ & $-81.1 \%$ \\
TC & 1.443 & 5.657 & $74.5 \%$ & $-74.5 \%$ \\
$\mathrm{PM}_{2.5}$ & 8.388 & 19.125 & $56.2 \%$ & $-56.1 \%$ \\
\hline
\end{tabular}

Table 3. Comparison of model results (in $\mu \mathrm{g} \mathrm{m}^{-3}$ ) for three test cases to observations from the Decatur monitor (\#130890002) in June and July 2002. Normalized mean error and normalized mean bias are shown.

\begin{tabular}{|c|c|c|c|c|}
\hline & & $\mathrm{TC} 1$ & TC2 & TC3 \\
\hline \multirow[t]{4}{*}{$\mathrm{NO}_{3}$} & test case mean & 0.463 & 0.460 & 0.461 \\
\hline & observed mean & 0.436 & 0.436 & 0.436 \\
\hline & norm mean error & $72.4 \%$ & $71.9 \%$ & $72.1 \%$ \\
\hline & norm mean bias & $6.1 \%$ & $5.4 \%$ & $5.7 \%$ \\
\hline \multirow{4}{*}{$\mathrm{SO}_{4}$} & test case mean & 2.426 & 2.415 & 2.420 \\
\hline & observed mean & 5.696 & 5.696 & 5.696 \\
\hline & norm mean error & $58.8 \%$ & $59.0 \%$ & $58.9 \%$ \\
\hline & norm mean bias & $-57.4 \%$ & $-57.6 \%$ & $-57.5 \%$ \\
\hline \multirow[t]{4}{*}{$\mathrm{NH}_{4}$} & test case mean & 0.970 & 0.965 & 0.967 \\
\hline & observed mean & 1.367 & 1.367 & 1.367 \\
\hline & norm mean error & $40.4 \%$ & $40.7 \%$ & $40.6 \%$ \\
\hline & norm mean bias & $-29.0 \%$ & $-29.4 \%$ & $-29.3 \%$ \\
\hline \multirow[t]{4}{*}{$\mathrm{EC}$} & test case mean & 0.763 & 0.759 & 0.762 \\
\hline & observed mean & 0.763 & 0.763 & 0.763 \\
\hline & norm mean error & $42.4 \%$ & $42.1 \%$ & $42.4 \%$ \\
\hline & norm mean bias & $-0.1 \%$ & $-0.6 \%$ & $-0.1 \%$ \\
\hline \multirow[t]{4}{*}{$\mathrm{OC}$} & test case mean & 1.025 & 1.023 & 1.024 \\
\hline & observed mean & 4.553 & 4.553 & 4.553 \\
\hline & norm mean error & $77.5 \%$ & $77.5 \%$ & $77.5 \%$ \\
\hline & norm mean bias & $-77.5 \%$ & $-77.5 \%$ & $-77.5 \%$ \\
\hline \multirow[t]{4}{*}{$\mathrm{TC}$} & test case mean & 1.787 & 1.782 & 1.787 \\
\hline & observed mean & 5.316 & 5.316 & 5.316 \\
\hline & norm mean error & $66.4 \%$ & $66.5 \%$ & $66.4 \%$ \\
\hline & norm mean bias & $-66.4 \%$ & $-66.5 \%$ & $-66.4 \%$ \\
\hline \multirow[t]{4}{*}{$\mathrm{PM}_{2.5}$} & test case mean & 8.508 & 8.482 & 8.496 \\
\hline & observed mean & 18.418 & 18.418 & 18.418 \\
\hline & norm mean error & $53.8 \%$ & $53.9 \%$ & $53.9 \%$ \\
\hline & norm mean bias & $-53.8 \%$ & $-53.9 \%$ & $-53.9 \%$ \\
\hline
\end{tabular}

in urban centers, with concentrations as low as $4.7 \mu \mathrm{g} \mathrm{m}^{-3}$ in rural regions (Fig. 2). The airport does not stand out in this figure because aircraft contribution to average surface $\mathrm{PM}_{2.5}$ was only $0.23 \mu \mathrm{g} \mathrm{m}^{-3}$ in the airport's grid cell.

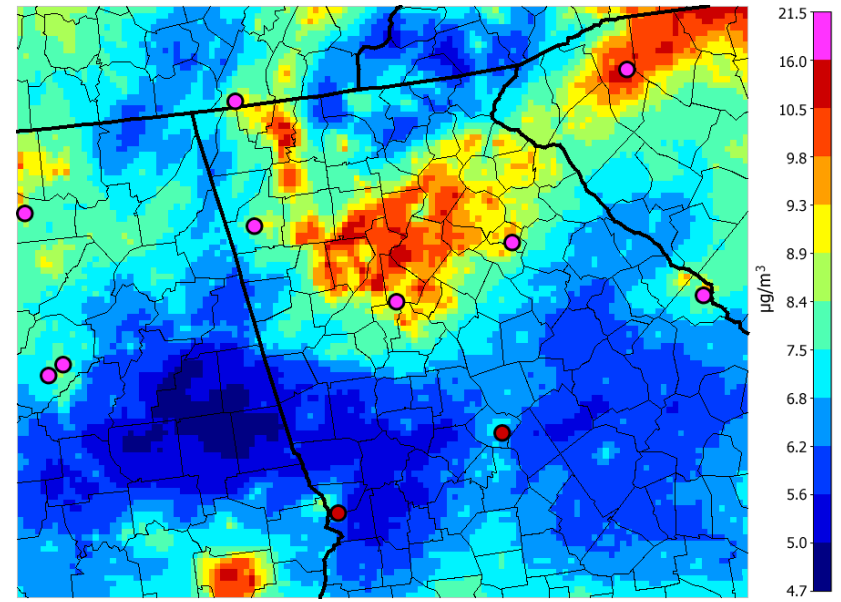

Fig. 2. Average modeled surface $\mathrm{PM}_{2.5}$ concentrations in June and July 2002 in TC1 (base case). Circles show the location of the air quality monitors in the domain and share the same color scale as the underlying tile plot.

\subsection{Aircraft impacts}

Aircraft increased the average concentration of total $\mathrm{PM}_{2.5}$ in June and July 2002 near the airport and throughout the Atlanta metro area (Fig. 3). Concentrations in the grid cell containing the airport were elevated by an average of $0.232 \mu \mathrm{g} \mathrm{m}^{-3}$. In the airport's grid cell, the contributions of species to aircraft impact on average $\mathrm{PM}_{2.5}$ were as follows: sulfate $(54 \%)$, elemental carbon $(28 \%)$, primary organic aerosol $(9 \%)$, ammonium $(8 \%)$, and nitrate $(1 \%)$. These results are comparable to those presented in Arunachalam et al. (2011).

Near the airport, aircraft raised sulfate concentrations by up to $0.130 \mu \mathrm{g} \mathrm{m}^{-3}$ (Fig. 3). In some areas far from Hartsfield-Jackson, aircraft caused very small reductions in sulfate aerosol concentrations $\left(<0.0005 \mu \mathrm{g} \mathrm{m}^{-3}\right)$. Tsai et al. (2001) observed a similar result when using a Lagrangian plume model to investigate aircraft impacts on sulfate pollution over Taiwan.

Aircraft increased elemental carbon concentrations near the airport by $0.036 \mu \mathrm{g} \mathrm{m}^{-3}$ (Fig. 3). As elemental carbon 

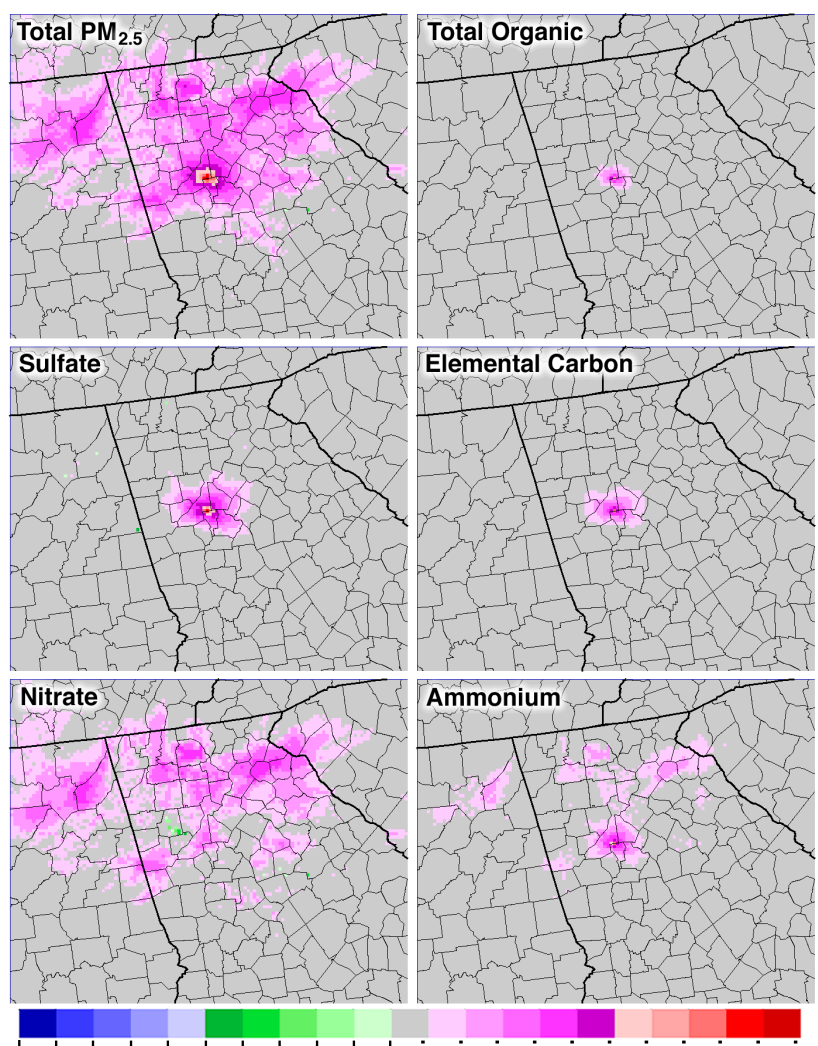

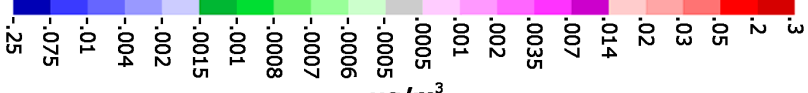
$\mu \mathrm{g} / \mathrm{m}^{3}$

Fig. 3. Aircraft impact on average surface concentrations of $\mathrm{PM}_{2.5}$ and five component species in June and July 2002 (i.e., base case TC1 minus no-aircraft case TC2).

is non-reactive in AMSTERDAM, the increase is due to direct elemental carbon emissions, and concentrations decrease with distance due to dilution and deposition. Aircraft also had a small positive effect on total organic PM concentrations (Fig. 3), almost all of which was due to POA. Like elemental carbon, POA is treated as a non-reactive species in AMSTERDAM, so the spatial impacts for elemental carbon and total organic PM look similar.

\subsection{Effects of the plume-in-grid process}

Figure 4 shows the results when TC3 (CMAQ without PinG) is subtracted from TC1 (the base case with PinG). Positive values indicate that the plume-in-grid process resulted in higher concentrations. In most grid cells, the use of PinG increased total $\mathrm{PM}_{2.5}$ concentrations by $0.0005-0.020 \mu \mathrm{g} \mathrm{m}^{-3}$. This may be due to a higher concentration of gas-phase precursors to secondary aerosols in the puffs, which are more likely to collide with each other when they are not diluted in a $4 \mathrm{~km}$ grid cell.

Except in the two cells nearest the airport, the entire eastwest line of cells containing the aircraft approach and depar-
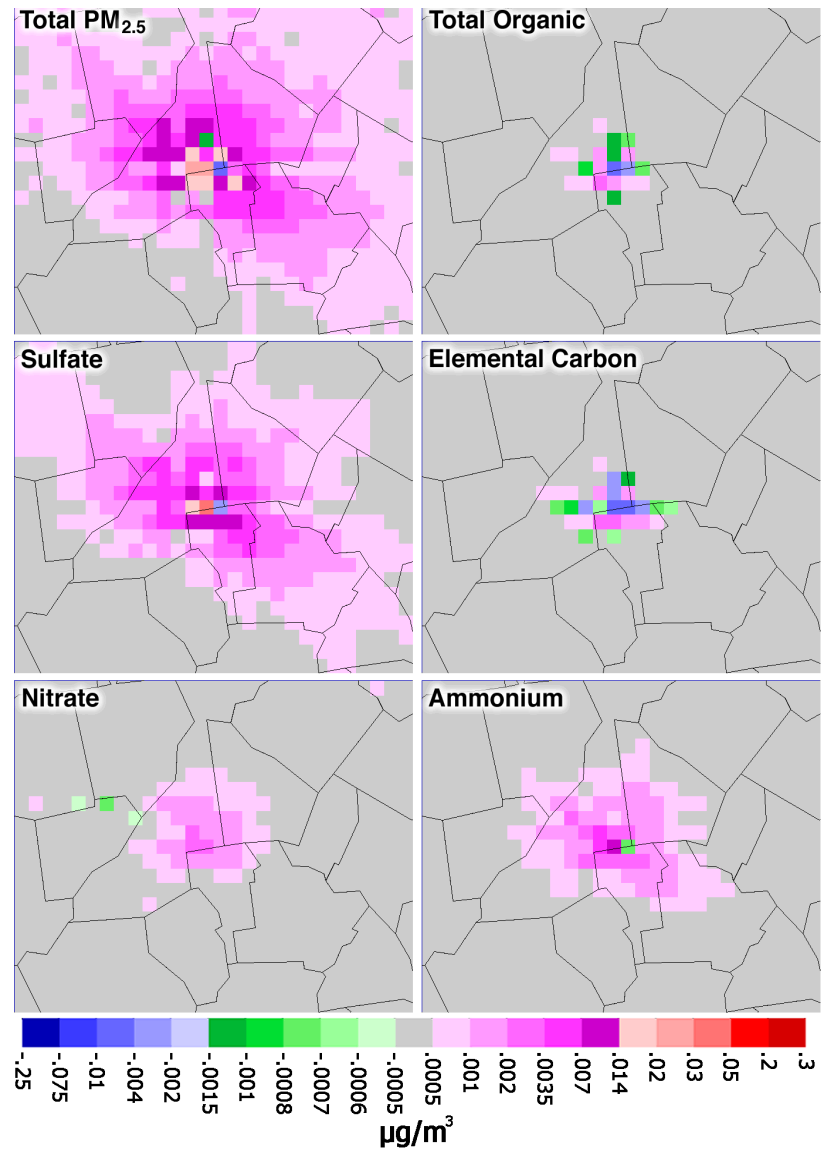

Fig. 4. Effects of plume-in-grid process on average surface concentrations of $\mathrm{PM}_{2.5}$ and five component species in June and July 2002 (i.e., base case TC1 minus no-PinG case TC3). Each panel shows a $92 \mathrm{~km}$ by $112 \mathrm{~km}$ area centered on the airport.

ture paths exhibited a smaller increase in total $\mathrm{PM}_{2.5}$ due to the PinG process than rows immediately above and below, indicating that there is a countervailing phenomenon operating in these cells. It is possible that the high altitude of emitters in these cells causes PM to remain above the ground layer in TC1, whereas downward movement of pollutants may be more rapid in TC3 when pollutants are not confined to puffs. One possible explanation for this difference is that puffs are emitted in the modeled domain at a higher temperature ( $643 \mathrm{~K}$ to $843 \mathrm{~K}$ depending on the aircraft engine mode) than the surrounding air and experience heat-driven "plume rise" which carries them upward. Pollutants added directly to the $4 \mathrm{~km}$ grid cell do not experience heat-driven plume rise, given their instantaneous dilution.

The PinG process increased concentrations of sulfate, nitrate, and ammonium aerosol in almost every cell. Sulfate experienced the largest increases, while the effects on nitrate were the smallest. The increase in sulfate and nitrate concentrations may be due the PinG process transporting inorganic gas-phase precursors away from urban areas and to 
areas where more ammonia is available to neutralize the sulfate and nitrate. Additionally, since this is a summer simulation, high temperatures favor the formation of ammonium sulfate over ammonium nitrate considering the semi-volatile nature of nitrate.

In most areas, particularly at the airport and along the approach and departure flight paths, use of the PinG process lowered elemental carbon concentrations by $0.0006-$ $0.010 \mu \mathrm{g} \mathrm{m}^{-3}$. In other areas, the PinG process increased elemental carbon concentrations. These changes likely relate to differences in transport between grid cells when the chemicals are confined to puffs. This may lead to slightly higher values in some grid cells and slightly lower values in others. Additionally, increasing elemental carbon (EC) concentration can increase their rate of coagulation into larger particles that deposit more rapidly. This may play a role in reducing (or limiting increases in) EC concentrations.

The results for organic PM are mixed. In most of the grid cells where emitters are located, the PinG process reduced organic PM concentrations. Aircraft influence on organic PM is overwhelmingly due to POA, which is considered nonreactive in AMSTERDAM and therefore may undergo increased deposition as for elemental carbon. However, 12 cells exhibit increased concentrations due to the PinG process. This may be due to differences in movement between cells when chemicals are confined to puffs, as well as the small contribution of secondary organic aerosol, which is formed in the atmosphere and may be increased by the PinG process due to more concentrated precursors.

\subsection{Examination of aircraft impacts at subgrid scale}

We instrumented AMSTERDAM to output the concentrations and centroid locations of all puffs in each timestep, and we compared the concentrations found within puffs to the aircraft contribution to the concentrations in underlying grid cells. Figure 5 shows the puffs that exist in one particular hour of the simulation (in all vertical layers) graphed on top of the aircraft contribution to grid cell concentrations in that same hour. The puffs originate along two eastwest lines that follow the approach and departure paths for each pair of runways at Hartsfield-Jackson. Puffs emitted in earlier model timesteps have been blown northward by prevailing winds, forming strands emerging from each emitter. Puffs near the airport are closer to the ground and have been blown slightly westward. Puffs farther from the airport are higher in altitude and have been blown slightly eastward. Newly generated puffs frequently have concentrations much higher than the aircraft contribution to the grid cells they contain. While some puffs have a concentration higher than $1.5 \mu \mathrm{g} \mathrm{m}^{-3}$ in this hour, no grid cells report an aircraft contribution higher than $0.314 \mu \mathrm{g} \mathrm{m}^{-3}$. Individual puffs may have aircraft-contributed $\mathrm{PM}_{2.5}$ up to 3 orders of magnitude larger than that modeled with coarse grid cells. However, it is important to remember that each emitter consolidates the emis-
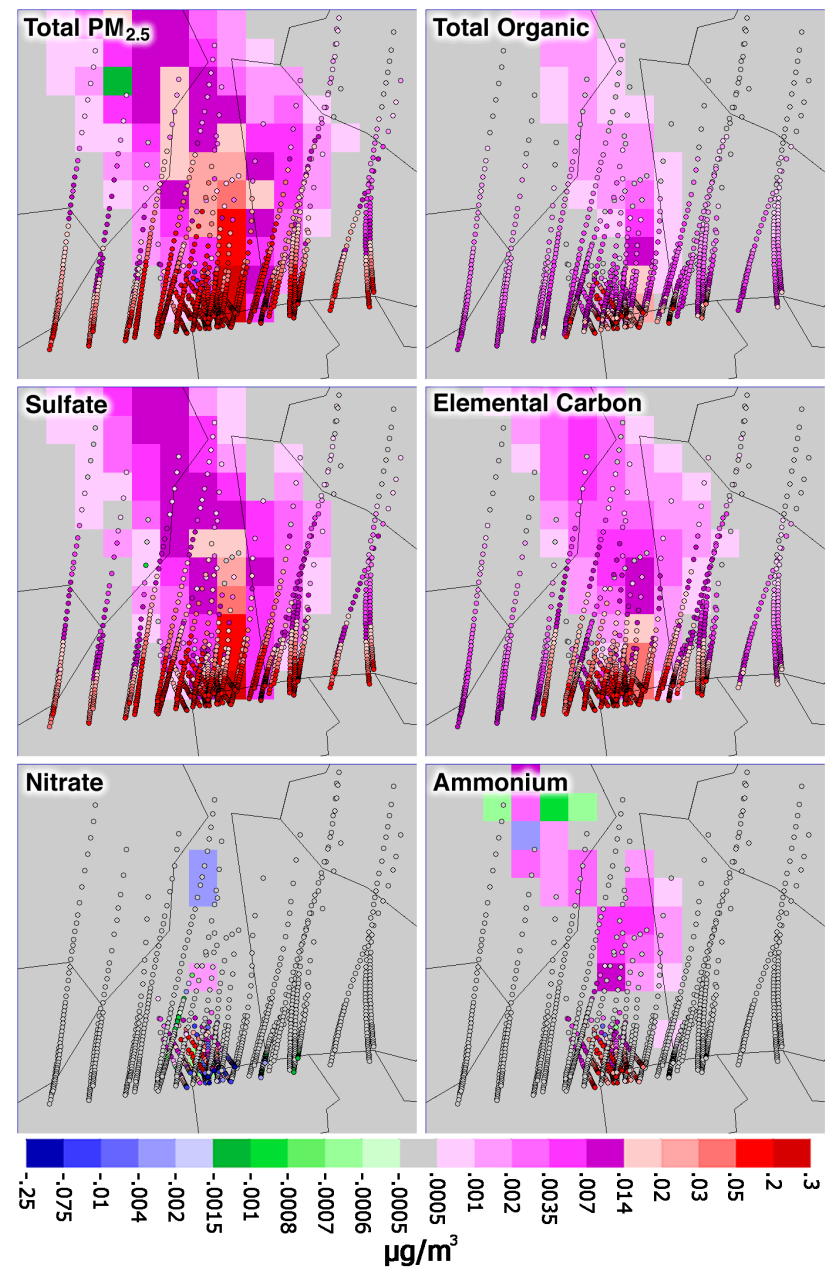

Fig. 5. Concentrations of six species due to aircraft in puffs and in grid cells (in all vertical layers) on 6 June at 11:00 UTC. Each panel shows a $52 \mathrm{~km}$ by $56 \mathrm{~km}$ area centered slightly north of the airport. Puffs and grid cells share the same color scale.

sions from aircraft along a short flight segment into a single point source emitter. Therefore, while the $4 \mathrm{~km}$ grid cells may artificially dilute emissions, point source emitters using our methodology may artificially concentrate emissions, and the true contributions of aircraft emissions near an airport may lie somewhere in between.

Figure 5 also shows that the largest aircraft influences are due to sulfate, which is only positive at close distances to the airport. The next most important species are elemental carbon and organic aerosols (overwhelmingly POA).

Next, we obtained puff concentrations of each species from each hour in June and July, and we analyzed the distribution of concentrations in comparison with the underlying grid cells, paired in space and time (i.e., grid cells that do not contain puffs are not included in this analysis). Up to $99 \%$ of all the aircraft-related puffs remain chemically active in the subgrid-scale phase at a distance of $60 \mathrm{~km}$ from the 

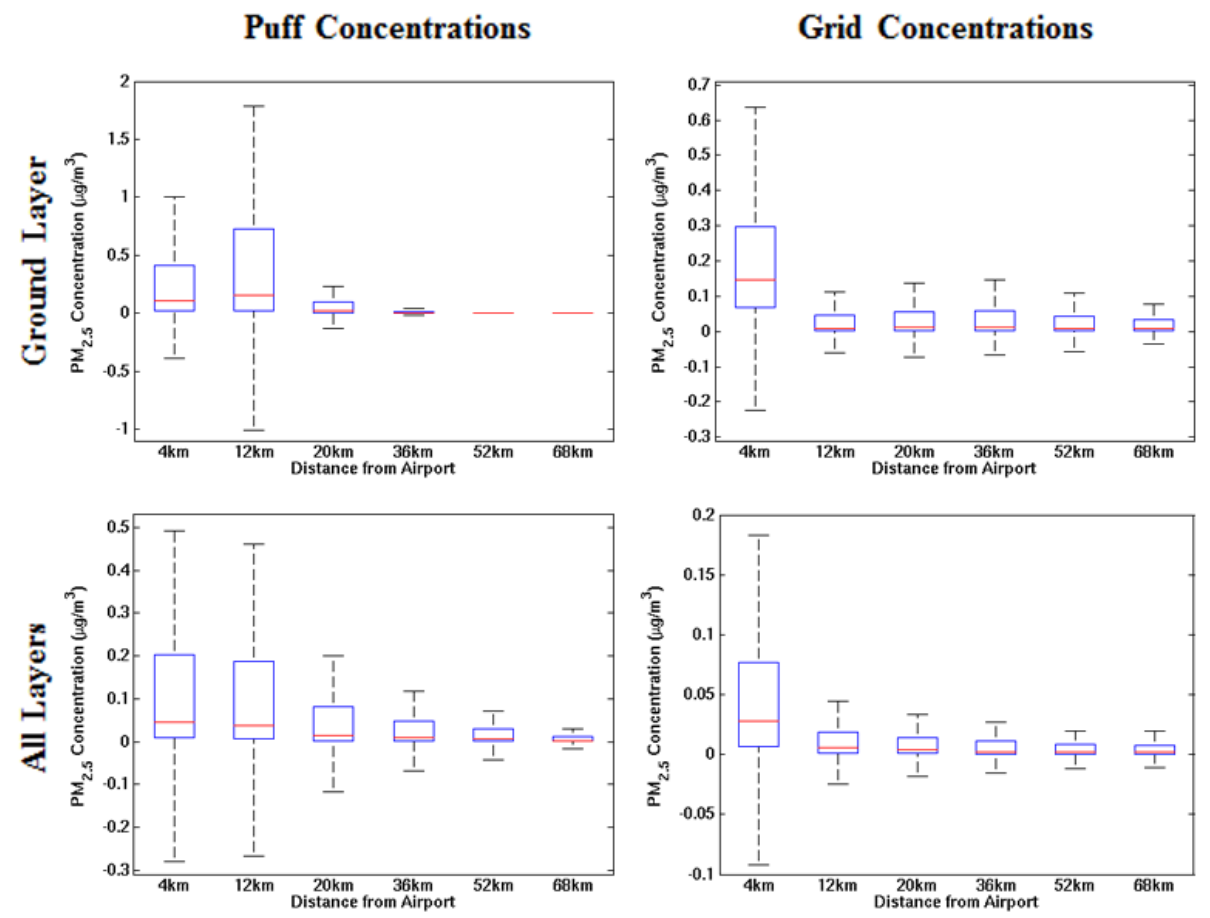

Fig. 6. Box-and-whisker plots showing the 25th, 50th (red line), and 75th percentiles, and maximum and minimum values (excluding outliers) of hourly $\mathrm{PM}_{2.5}$ concentrations in puffs and in aircraft contribution to grid cells at various distances in the modeled surface layer, and in all layers. Outliers are defined as values more than 1.5 times the inter-quartile range above the 75 th percentile and below the 25 th percentile. All timesteps are included separately (i.e., not averaged), forming the distributions. The analysis includes only those grid cells in the outermost ring as we go outward from the airport, and thus no overlap of grid cells between each box-and-whisker. Note that the vertical axis scale varies by graph.

airport, with a few puffs active even at a distance of $145 \mathrm{~km}$, before they are merged into the host grid in CMAQ based upon physical criteria for puff maturity, as described earlier. Twenty-one (21) \% of all aircraft-related puffs from the Atlanta airport have at least $0.1 \mu \mathrm{g} \mathrm{m}^{-3} \mathrm{PM}_{2.5}$ concentrations (mean of $0.14 \mu \mathrm{g} \mathrm{m}^{-3}$ and max. of $42.1 \mu \mathrm{g} \mathrm{m}^{-3}$ from all puffs during the 2-month simulation). In order to better understand air quality impacts due to aircraft emissions as distance from the airport increases, we performed this comparison for six concentric rings (or domains) centered on the airport: a $68 \mathrm{~km} \times 68 \mathrm{~km}$ region, $52 \mathrm{~km} \times 52 \mathrm{~km}, 36 \mathrm{~km} \times 36 \mathrm{~km}$, $20 \mathrm{~km} \times 20 \mathrm{~km}, 12 \mathrm{~km} \times 12 \mathrm{~km}$, and $4 \mathrm{~km} \times 4 \mathrm{~km}$ (i.e., the airport's own grid cell), as shown in Fig. 6. In the $4 \mathrm{~km} \times 4 \mathrm{~km}$ and $12 \mathrm{~km} \times 12 \mathrm{~km}$ domains, concentrations in puffs are higher than the aircraft contribution to the grid cells for all statistics except the minimum values. For the minimum values, the puffs are at least $50 \%$ more negative than the most negative aircraft contribution to a grid cell. (CMAQAMSTERDAM treats the aircraft sources in the subgridscale as perturbations, and hence a negative concentration in a puff implies that the total concentration near the puff is less than the background concentration in the grid cell.) This confirms that our finding that puffs generally have much higher concentrations than the underlying aircraft contribu- tion to grid cells near the airport (Fig. 5) holds true across the entire two-month period. When we include the outliers from the distribution for each concentric ring (Fig. S2 in the Supplement), the maximum incremental concentrations due to aircraft emissions can be as high as $42.1 \mu \mathrm{g} \mathrm{m}^{-3}$ in the surface layer. Furthermore, when we include all layers in the analyses, the maximum concentrations aloft can be as high as $38 \mu \mathrm{g} \mathrm{m}^{-3}$ within the airport's $4 \mathrm{~km}$ grid cell. However, the general pattern in grid averages at varying distances does not change much when we include only the surface layer versus all layers. The highest concentrations within puffs tend to be within the $12 \mathrm{~km} \times 12 \mathrm{~km}$ domain, while the greatest impacts in grid cells tend to be in the airport's own grid cell (Fig. 7), indicating that confining pollutants to puffs may result in easier or more rapid downwind transport.

We also examined the chemical composition of puffs and of aircraft impact on grid cells in these domains. In Fig. 7, we present the $\mathrm{PM}_{2.5}$ composition in the puff or grid cell with median concentrations in each concentric ring in the surface layer and in all layers. Note that the median puff concentration in the ground layer at $12 \mathrm{~km}$ distance is more than 15 times that of the aircraft contribution to the underlying grid cell, but at distances at least $36 \mathrm{~km}$ from the airport, contribution to grid cells is higher than puff concentrations. We 


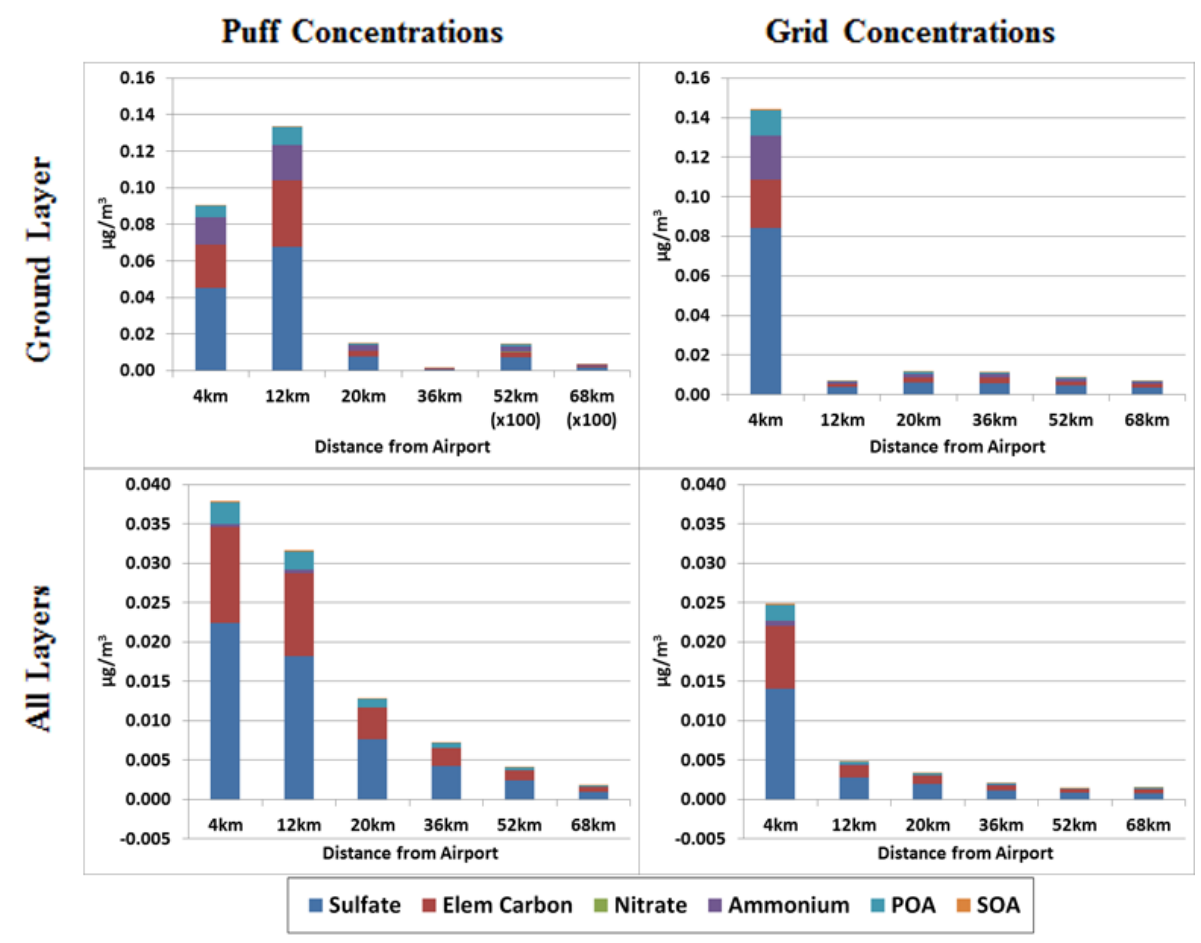

Fig. 7. Median hourly concentration of $\mathrm{PM}_{2.5}$ component species (during June-July 2002) in puffs and in aircraft contribution to grid cells at various distances in the surface layer and in all layers. The analysis includes only those grid cells in the outermost ring as we go outward from the airport, and thus no overlap of grid cells in each bar. Note that the vertical axis scale varies by graph.

find that aircraft contribution to grid cells follows a slightly different pattern from puff concentrations, with the highest magnitude impacts in the $4 \mathrm{~km} \times 4 \mathrm{~km}$ domain, likely due to the instantaneous mixing in the grid cells where emissions occur. Sulfate is the most important component of aircraft contribution to grid cells at ground level, followed by elemental carbon, ammonium, and primary organic matter. This confirms that most of our speciated findings for one timestep (Fig. 5) also hold true across the model run; the exception is that ammonium concentration is slightly larger than primary organic matter concentration (rather than slightly smaller).

Speciated results for puffs, shown in Fig. 7 (for median puff/grid cell concentrations) and in Fig. S2 in the Supplementary Materials (maximum concentrations), indicate that the most important species in puffs are the same as those in grid cells, except ammonium in puffs is not significant in layers aloft. In contrast, ammonium is significant for puffs near the surface. Ammonium contributions are significant within grid cells at the surface but decrease aloft (Fig. 7), while sulfate contributions are significant both at the surface and aloft. This may be attributable to the fact that ammonia is primarily emitted from agricultural operations and other anthropogenic activities at the surface, while smokestacks (treated within the grid in this application) and aircraft emit sulfate and $\mathrm{SO}_{2}$ aloft. Additional analysis presenting speciated values of median $\mathrm{PM}_{2.5}$ concentrations from puffs and grid cells is included in the Supplementary Materials.
Finally, we analyze variability in the median concentrations of puffs and median aircraft contribution to grid cells in several concentric rings near the airport for each day of the run (Fig. 8). Note that this daily variability during the modeling period is presented only for 3 rings in Fig. 8, as opposed to 6 rings in Fig. 7 for ease of readability. The highest median puff as well as grid concentrations are found in the $4 \mathrm{~km} \times 4 \mathrm{~km}$ domains followed by $36 \mathrm{~km} \times 36 \mathrm{~km}$ and then $68 \mathrm{~km} \times 68 \mathrm{~km}$.

We also analyzed the daily variability in maximum concentrations (Fig. S3 in the Supplement) in the puffs and grid cells. The general trends in magnitudes of maximum concentrations in puffs in various rings do not change much with time, where the highest is seen in the $4 \mathrm{~km} \times 4 \mathrm{~km}$, followed by the $36 \mathrm{~km} \times 36 \mathrm{~km}$ (except for couple of days in June) and then the $68 \mathrm{~km} \times 68 \mathrm{~km}$. However, within the grid cells, the daily variability is quite high, where the maxima fluctuate between the first $4 \mathrm{~km} \times 4 \mathrm{~km}$ and the $36 \mathrm{~km} \times 36 \mathrm{~km}$, followed by the $68 \mathrm{~km} \times 68 \mathrm{~km}$ ring. This is an indication of the variability in underlying transport patterns and in the times of puffs merging their concentrations with the underlying grid cells. When including all layers, the maximum puff concentrations also seem to fluctuate between the various domains. Furthermore, the maximum concentrations for each day (Fig. S3) exceed the median (Fig. 8) by a factor of up to 100 in the case of puffs, and by a factor of up to 6 in the case of grid cells. Also, while the general ranges of median 


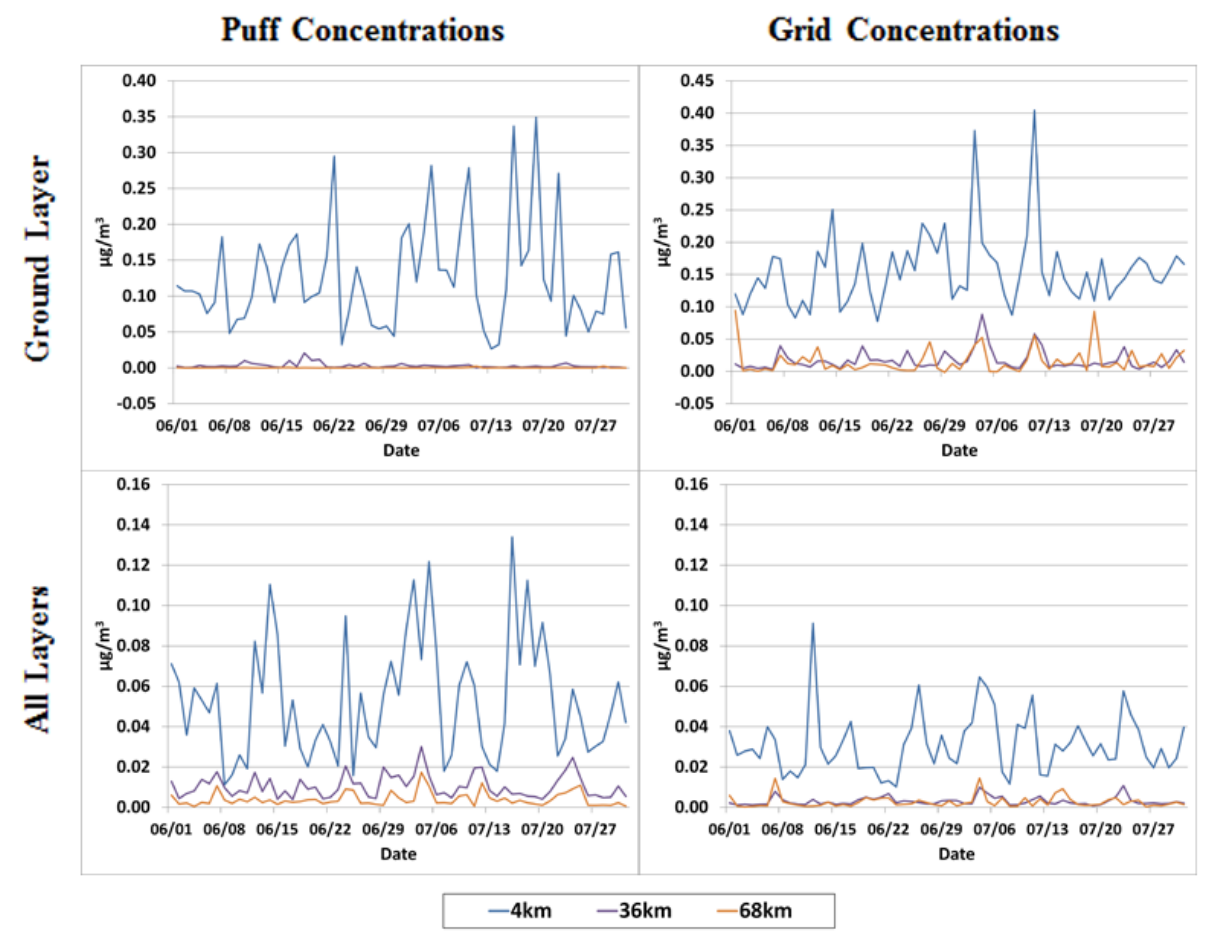

Fig. 8. Median hourly $\mathrm{PM}_{2.5}$ concentrations for each day in puffs and in airport contribution to grid cells at various distances in modeled surface layer, and in all layers, during June and July 2002. The analysis includes only those grid cells in the outermost ring as we go outward from the airport, and thus no overlap of grid cells in each bar. Note that the vertical axis scale varies by graph.

concentrations in puffs are comparable to those in the grid cells (Fig. 8), the daily maximum concentrations in puffs are usually 10-20 times higher (Fig. S3) than the underlying grid cells. Excluding outliers and examining the whole model run (Fig. 6), maximum puff concentrations were 16 times higher than the maximum grid cell concentrations at the same distance from the airport and 3 times higher than the highest concentration in the airport's own grid cell. These results emphasize that use of a subgrid-scale treatment may be less important if one seeks to understand only median impacts, but the technique has great value in revealing potential maximum impacts that are masked by grid-scale modeling, though confirmation of any given plume model's treatment of chemical and physical mechanisms through in-plume measurements will be important to refine and increase the confidence of estimates produced by this technique.

\section{Conclusions}

We have successfully implemented a novel approach for modeling aircraft emissions at a major US airport using a plume-in-grid modeling technique to assess the subgrid-scale variability of aircraft impacts.

Impact of aircraft: In June and July 2002, aircraft emissions during LTO contributed $0.232 \mu \mathrm{g} \mathrm{m}^{-3}$ to average $\mathrm{PM}_{2.5}$ concentrations in the airport's grid cell and between 0.001 and $0.007 \mu \mathrm{g} \mathrm{m}^{-3}$ in a multi-county region covering more than 15000 square kilometers. At the airport, aircraft contribute $54 \%$ of total $\mathrm{PM}_{2.5}$ as sulfate aerosol, $28 \%$ as elemental carbon, $9 \%$ as primary organic aerosol, and $8 \%$ as ammonium. Far from the airport, aircraft decrease sulfate concentrations by up to $0.0005 \mu \mathrm{g} \mathrm{m}^{-3}$.

Effects of PinG process: Use of a plume-in-grid process for modeling aircraft emissions tends to increase the concentrations of secondary PM pollutants by $0.0005-0.020 \mu \mathrm{g} \mathrm{m}^{-3}$ in a multi-county area surrounding the airport, likely due to increased concentration of reactants when consolidated into puffs. For non-reactive primary pollutants, such as POA and EC, the PinG process tends to lower concentrations in grid cells where emitters are located by up to $0.010 \mu \mathrm{g} \mathrm{m}^{-3}$, and concentrations in nearby areas are sometimes increased by up to $0.003 \mu \mathrm{g} \mathrm{m}^{-3}$. These changes are likely due to differences in pollutant transport when pollutants are confined to puffs and hence transported further downwind from the source regions. Increased coagulation and resulting deposition may also affect concentrations. Model performance analysis did not find significant differences in error and bias between a model run that utilized the PinG process and one that did not, so it is unclear whether the PinG process improves model performance based upon monitoring data available in the region.

Subgrid-scale analysis: In the airport's grid cell, at ground level, puffs generally have maximum concentrations roughly 
$50 \%$ higher than maximum aircraft contribution to the grid cell (ignoring outliers). In a square, $12 \mathrm{~km}$-diameter ring, puff maximum concentrations exceed maximum aircraft grid cell contributions by a factor of 16 , while maximum concentrations are comparable in a $20 \mathrm{~km}$ ring. At greater distances, maximum grid cell contribution exceeded maximum puff concentrations. Median aircraft contribution to grid cells is higher than median puff concentration in the airport's grid cell and outside of a $20 \mathrm{~km} \times 20 \mathrm{~km}$ ring centered on the airport, while in a $12 \mathrm{~km} \times 12 \mathrm{~km}$ ring centered on the airport, puffs have median concentrations over an order of magnitude higher than aircraft contribution to the grid cells. Maximum puff impacts are seen within the $12 \mathrm{~km} \times 12 \mathrm{~km}$ ring, not in the airport's own grid cell, while maximum grid cell impacts occur within the airport's grid cell. Twenty-one (21) $\%$ of all aircraft-related puffs from the Atlanta airport have at least $0.1 \mu \mathrm{g} \mathrm{m}^{-3} \mathrm{PM}_{2.5}$ concentrations. Median daily puff concentrations vary between 0.017 and $0.134 \mu \mathrm{g} \mathrm{m}^{-3}$, while maximum daily puff concentrations vary between 6.1 and $42.1 \mu \mathrm{g} \mathrm{m}^{-3}$ during the 2-month period. Except for ammonium aloft, the component species in puffs are the same species that compose aircraft contribution to grid cells, in roughly the same ratios.

Sources of uncertainty: There are many sources of uncertainty affecting our results in ways that are difficult to characterize numerically. These include imperfections and assumptions inherent in gridded meteorological input data, a lack of knowledge of precise aircraft timing and trajectories, uncertainty in engine emissions estimates, the need to use a finite number of emitters to represent moving aircraft, simplifications in the model's chemical mechanism which reduce hundreds of real-world species to a smaller number of model species, and potential undiscovered errors in the model.

There are a number of areas future researchers might consider to extend this work. There were no plume-scale measurements available in the Atlanta region for evaluating the plume processes in AMSTERDAM. Future studies should focus on applying and evaluating AMSTERDAM with inplume data that may be available from previous or future field campaigns. While this study emphasizes the modeling of concentrations at subgrid scales within a plume due to aircraft emissions, we caution that this capability has not been fully evaluated against measurements. Model evaluation against measurements from aircraft-related plumes will provide additional confidence in subgrid-scale results presented here. Many airports in the US have existing emissions inventories, which were produced via the EDMS model. A program could be developed which reads EDMS emission outputs and generates a set of PinG input files for AMSTERDAM on the basis of those emissions (for instance, by placing an emitter in the center of each EDMS grid cell). This would allow AMSTERDAM to be used efficiently to model the impacts from many airports using existing EDMS-based emissions inventories. Similarly, a program could be developed to adapt the new AEDT global inventories for use in
AMSTERDAM. We are aware of ongoing work in this area already.

CMAQ-AMSTERDAM currently assigns $99.9 \%$ of PEC and POA emissions (from all sources, including aircraft) to the accumulation mode (particles of size between 0.1 and $2.5 \mu \mathrm{m}$ with geometric mean particle diameter (GMDV) of $300 \mathrm{~nm}$ ), and $0.1 \%$ to the Aitken mode (particles of size $<0.1 \mu \mathrm{m}$ with GMDV of $30 \mathrm{~nm}$ ). A series of commercial aircraft engine measurements performed under the Aircraft Particle Emissions eXperiments (APEX) 1-3 showed that the GMDV for aircraft emissions range from 9.4 to $37 \mathrm{~nm}$ for various engines under different test conditions (Kinsey et al., 2010). It is clear that the aircraft emissions are closer to what CMAQ assumes as the Aitken mode rather than the accumulation mode. Future work should explore assigning aircraft emissions to the Aitken mode and assess the impacts of this change on predicted aerosol concentrations.

Although this study examined only a past year (2002), a similar technique could be used to model emissions in a future year, assuming changes in background emissions (due to new or improved control technologies, regulations, changes in GDP, etc.) and differences in aircraft emissions (due to changes in fleet composition, air travel demand, engine technology, etc.). The future year assessment is of interest given the significant contributions of background emissions to future year air quality impacts due to aviation growth as demonstrated by Woody et al. (2011). Modeling a complete year, or at least both the summer and winter seasons, may give a more complete impression of how aircraft influence PM concentrations in the region, especially when longterm (such as annual) average impacts are of interest.

Additional work is ongoing to improve ADSC to model organics and volatile PM. Recent work by Miracolo et al. (2011) show that aircraft emissions can form much higher levels of SOA when non-traditional precursors are considered. Incorporating these updates will likely improve CMAQ's SOA performance, enhance our understanding, and increase the magnitude of the aircraft contribution to total $\mathrm{PM}_{2.5}$.

Since AMSTERDAM was created, enhanced aerosoland gas-phase chemistry routines have been developed for CMAQ. AMSTERDAM uses aerosol treatment AERO-3 and chemical mechanism CB-IV, while the latest versions are AERO6 and CB05 in CMAQv5. Additionally, the Regional Atmospheric Chemical Mechanism version 2 (RACM2) has been recently implemented in CMAQ v5 (Sarwar et al., 2013). Future researchers may wish to incorporate these routines into AMSTERDAM, or use a different subgrid-scale process in a model that natively uses these routines.

This work only included LTO cycle emissions due to our focus on assessing their impacts on surface air quality near the airport, and thus excluded the impacts of aircraft emissions during cruise mode at higher altitudes. Researchers may consider including cruise mode emissions in future sim- 
ulations, particularly when studying emissions impacts in a larger region.

Finally, this work modeled the airport with a set of 51 static emitters. Future researchers may consider using a greater number of emitters to determine influences on model accuracy and the increased computational resources necessary to perform a simulation with more emitters. They may also consider extending AMSTERDAM to enable the use of moving, elevated emitters.

\section{Supplementary material related to this article is available online at http://www.atmos-chem-phys.net/13/ 9285/2013/acp-13-9285-2013-supplement.zip.}

Acknowledgements. This work was funded by the FAA, NASA, EPA, DOD and Transport Canada under FAA grant no. 07-C-NEUNC, amendment nos. 001 to 005, and 09-C-NE-UNC amendment nos. 001 to 004 under the Partnership for AiR Transportation Noise \& Emissions Reduction (PARTNER). The authors would like to acknowledge the Georgia Department of Natural Resources; CSSI, Inc.; Lawrence Rissman; Neil Davis; and Mark Reed for their support with this project. We also thank Prakash Karamchandani and the Electric Power Research Institute (EPRI)'s Eladio Knipping and Naresh Kumar for making AMSTERDAM available to us before its public release; Mohan Gupta and Christopher Sequeira of the FAA, who managed this project; and the two reviewers whose comments greatly enhanced this manuscript. Any opinions, findings, conclusions, or recommendations are those of the authors and do not necessarily reflect the opinions of PARTNER or its sponsors.

Edited by: S. Galmarini

\section{References}

Air New Zealand: Aircraft Statistics, available at: http://www. airnewzealand.co.nz/aircraft-statistics (last access: 22 June 2013), 2013.

Airports Council International: ACI releases World Airport Traffic Report 2009, available at: http://www.aci.aero/Media/aci/file/ PressReleases/2010/PR_WATR2009_050810_FINAL.pdf (last access: 4 January 2013), 2010.

Airports Council International: Annual Traffic Data (Movements) for years 2002 and 2005, available at: http://www.aci.aero/ Data-Centre/Annual-Traffic-Data/Movements/ (last access: 16 February 2013), 2013.

Arunachalam, S., Baek, B. H., Holland, A., Adelman, Z., Binkowski, F. S., Hanna, A., Thrasher, T., and Soucacos, P.: An Improved Method to Represent Aviation Emissions in Air Quality Modeling Systems and their Impacts on Air Quality, in: Proceedings of the 13 Conference on Aviation, Range and Aerospace Meteorology, New Orleans, LA, January 2008, 135626, available at: https://ams.confex.com/ams/ pdfpapers/135626.pdf (last access: 30 November 2012), 2008.
Arunachalam, S., Wang, B., Davis, N., Baek, B. H., and Levy, J. I.: Effect of Chemistry-Transport Model Scale and Resolution on Population Exposure to $\mathrm{PM}_{2.5}$ from Aircraft Emissions during Landing and Takeoff, Atmos. Environ., 45, 3294-3300, doi:10.1016/j.atmosenv.2011.03.029, 2011.

Aviation Environmental Design Tool: http://www.faa.gov/about/ office_org/headquarters_offices/apl/research/models/aedt/ (last access: 25 October 2010), 2010.

Baek, B. H., Arunachalam, S., Holland, A., Adelman, Z., Hanna, A., Thrasher, T., and Soucacos, P.: Development of an Interface for the Emissions Dispersion and Modeling System (EDMS) with the SMOKE Modeling System, in: Proceedings of the $16^{\text {th }}$ Annual Emissions Inventory Conference, Emissions Inventories: Integration, Analyses and Communication, Raleigh, NC, May 2007, available at: http://www.epa.gov/ttn/ chief/conference/ei16/session1/baek.pdf (last access: 30 November 2012), 2007.

Barrett, S. R. H., Britter, R. E., and Waitz, I. A.: Global mortality attributable to aircraft cruise emissions, Environ. Sci. Technol., 44, 7736-7742, 2010.

Byun, D. W. and Schere, K. L.: Review of the Governing Equations, Computational Algorithms, and Other Components of the Models-3 Community Multiscale Air Quality (CMAQ) Modeling System, J. Appl. Mech. Rev., 59, 51-77, doi:10.1115/1.2128636, 2006.

Cimorelli, A., Perry, S., Venkatram, A., Weil, J., Paine, R., Wilson, R., Lee, R., Peters, W., and Brode, R.: AERMOD: A dispersion Model for Industrial Source Applications. Part I: General Model Formulation and Boundary Layer Characterization, J. Appl. Meteorol., 44, 682-693, doi:10.1175/JAM2227.1, 2005.

Eyers, C., Gilboy, M.: Revision of Calvert method for filling in missing smoke number data, QinetiQ, 2007.

FAA and EPA: Recommended Best Practice for Quantifying Speciated Organic Gas Emissions from Aircraft Equipped with Turbofan, Turbojet, and Turboprop Engines, http://www. faa.gov/regulations_policies/policy_guidance/envir_policy/ media/FAA-EPA_RBP_SpeciatedOG_Aircraft_052709.pdf (last access: 28 February 2011), 2009.

Federal Aviation Administration: Emissions and Dispersion Modeling System (EDMS) policy for airport air quality analysis: Interim guidance to FAA Orders 1050.1D and 5050.4A, Federal Register, 63, 18068, available at: http://www.faa.gov/about/office_org/ headquarters_offices/apl/research/models/edms_model/media/ EDMSRequirementforAirportAirQualityAnalysis.pdf (last access: 30 November 2012), 1998.

Gery, M. W., Whitten, G. Z., Killus, J. P., and Dodge, M. C.: A photochemical kinetics mechanism for urban and regional scale computer modeling, J. Geophys. Res.-Atmos., 94, 12925-12956, doi:10.1029/JD094iD10p12925, 1989.

Gladstone, C., Glover, G., Massimini, P., Skiotsuki, C., and Simmons, B.: Analysis of Triple Arrivals to Hartsfield Atlanta International Airport, MITRE Technical Report, available at: http: //www.caasd.org/library/tech_docs/2000/mtr00w0000023.pdf (last access: 6 March 2011), 2000.

Grell, G., Dudhia, J., and Stauffer, D.: A Description of the Fifth-Generation Penn State/NCAR Mesoscale Model (MM5), NCAR Technical Note, available at: http://nldr.library.ucar.edu/ 
repository/assets/technotes/asset-000-000-000-214.pdf (last access: 30 December 2011), 1994.

Hall, C., Mondoloni, S., and Thrasher, T.: Estimating the Impact of Reduced Thrust Takeoff on Annual $\mathrm{NO}_{\mathrm{x}}$ Emissions at Airports, CSSI, Inc., available at: http://www.cssiinc.com/public/technicalpapers/docs/13-

Estimating the Impact of Reduced Thrust Takeoff on Annual NOx Emissions.pdf (last access: 16 February 2011), 2003.

Herndon, C., Jayne, J., Lobo, P., Onasch, T., Fleming, G., Hagen, D., Whitefield, P., and Miake-Lye, R.: Commercial Aircraft Engine Emissions Characterization of in-Use Aircraft at HartsfieldJackson Atlanta International Airport, Environ. Sci. Technol., 42, 1877-1883, available at: http://www.volpe.dot.gov/coi/ees/ air/docs/2008-envi-sci-herndon.pdf, 2008.

Houyoux, M. R., Vukovich, J. M., Coats Jr., C. J., Wheeler, N. J. M., and Kasibhatla, P. S.: Emission inventory development and processing for the seasonal model for regional air quality (SMRAQ) project, J. Geophys. Res., 105, 9079-9090, 2000.

International Civil Aviation Organization (ICAO): International Standards and Recommended Practices - Environmental Protection Volume II, Second Edition, 1993.

International Civil Aviation Organization (ICAO): Emissions Databank Issue 17, http://www.caa.co.uk/default.aspx?catid= 702 (last access: 28 February 2011), 2010.

Karamchandani, P., Seigneur, C., Vijayaraghavan, K., and Wu, S. Y.: Development and application of a state-of-the-science plume-in-grid model, J. Geophys. Res-Atmos., 107, 4403-4415, doi:10.1029/2002JD002123, 2002.

Karamchandani, P., Vijayaraghavan, K., Chen, S., Seigneur, C., and Edgerton, E.: Plume-in-grid modeling for particulate matter, Atmos. Environ., 40, 7280-7297, doi:10.1016/j.atmosenv.2006.06.033, 2006.

Karamchandani, P., Lohman, K., Seigneur, C.: Using a sub-grid scale modeling approach to simulate the transport and fate of toxic air pollutants, Environ. Fluid Mech., 9, 59-71, 2009.

Karamchandani, P., Vijayaraghavan, K., Chen, S., BalmoriBronson, R., Knipping, E.: Development and application of a parallelized version of the advanced modeling system for transport, emissions, reactions and deposition of atmospheric matter (AMSTERDAM): 1. Model performance evaluation and impacts of plume-in-grid treatment, Atmos. Poll. Res., 1, 260-270, doi:10.5094/APR.2010.033, 2010.

Kinsey, J. S., Dong, Y., Williams, D. C., and Logan, R.: Physical Characterization of the fine particle emissions from commercial aircraft engines during the Aircraft Particle Emissions Experiment (APEX) 1-3, Atmos. Environ., 44, 2147-2156, doi:10.1016/j.atmosenv.2010.02.010, 2010.

Kraabøl, A., Flatøy, F., and Stordal, F.: Impact of $\mathrm{NO}_{\mathrm{x}}$ emissions from subsonic aircraft: Inclusion of plume processes in a three-dimensional model covering Europe, North America, and the North Atlantic, J. Geophys. Res.-Atmos., 105, 3573-3581, doi:10.1029/1999JD900931, 2000.

Kraabøl, A., Berntsen, T., Sundet, J., and Stordal, F.: Impacts of $\mathrm{NO}_{\mathrm{x}}$ emissions from subsonic aircraft in a global threedimensional chemistry transport model including plume processes, J. Geophys. Res.-Atmos., 107, ACH 22-1-ACH 22-13, doi:10.1029/2001JD001019, 2002.
Lee, H., Olsen, S. C., Wuebbles, D. J., and Youn, D.: Impacts of aircraft emissions on the air quality near the ground, Atmos. Chem. Phys., 13, 5505-5522, doi:10.5194/acp-13-5505-2013, 2013.

Levy, J., Hsu, H., and Melly, S.: High Priority Compounds Associated with Aircraft Emissions: PARTNER 11 final report on subtask: Health Risk Prioritization of Aircraft Emissions Related Air Pollutants, Partnership for AiR Transportation Noise and Emissions Reduction, available at: http://web.mit.edu/ aeroastro/partner/reports/proj11/p11compndsemiss.pdf (last access: 10 Apr 2011), 2008.

Levy, J. I., Woody, M., Baek, B. H., Shankar, U., and Arunachalam, S.: Current and Future Particulate Matter-related Mortality Risks from Aviation Emissions in the United States, Risk Anal., 32, 237-249, doi:10.1111/j.1539-6924.2011.01660.x, 2012.

Meilinger, S., Kärcher, B., and Peter, T.: Microphysics and heterogeneous chemistry in aircraft plumes - high sensitivity on local meteorology and atmospheric composition. Atmos. Chem. Phys., 5, 533-545, doi:10.5194/acp-5-533-2005, 2005.

Miracolo, M. A., Hennigan, C. J., Ranjan, M., Nguyen, N. T., Gordon, T. D., Lipsky, E. M., Presto, A. A., Donahue, N. M., and Robinson, A. L.: Secondary aerosol formation from photochemical aging of aircraft exhaust in a smog chamber, Atmos. Chem. Phys., 11, 4135-4147, doi:10.5194/acp-11-4135-2011, 2011.

Moss, M. and Segal, H.: Emissions and Dispersion Modeling System: Its Development and Application at Airports and Airbases, J. Air Waste Manage., 44, 787-790, doi:10.1080/1073161X.1994.10467281, 1994.

Naiman, A. D., Lele, S. K., Wilkerson, J. T., and Jacobson, M. Z.: Parameterization of subgrid plume dilution for use in large-scale atmospheric simulations, Atmos. Chem. Phys., 10, 2551-2560, doi:10.5194/acp-10-2551-2010, 2010.

Noel, G., Cointin, R., Allaire, D., Jacobson, S., and Willcox, K.: Assessment of the Aviation Environmental Design Tool, 8th USA/Europe Air Traffic Management Research and Development Seminar, Napa, CA, 29 June-9 July 2009, 84, available at: http://www.atmseminarus.org/seminarContent/seminar8/ papers/p_084_EI.pdf (last access: 30 November 2012), 2009.

Pope, C., Burnett, R., Thun, M., Calle, E., Krewski, D., Ito, K., and Thurston, G.: Lung cancer, cardiopulmonary mortality, and longterm exposure to fine particulate air pollution, JAMA-J. Am. Med. Assoc., 287, 1132-1141, doi:10.1001/jama.287.9.1132, 2002.

Ratliff, G., Sequeira, C., Waitz, I., Ohsfeldt, M., Thrasher, T., Graham, M., and Thompson, T.: Aircraft Impacts on Local and Regional Air Quality in the United States, Partnership for Air Transportation Noise and Emissions Reduction, available at: http://web.mit.edu/aeroastro/partner/reports/proj15/ proj15finalreport.pdf (last access: 24 March 2011), 2009.

Rice, C.: Validation of Approach and Climbout Times-in-Mode for Aircraft Emissions Computation, 2003 Transportation Research Board Annual Meeting, Washington, DC, 12 Jan 2003, available at: http://www.ltrc.lsu.edu/TRB_82/TRB2003-001446.pdf (last access: 30 November 2012), 2003.

Santos, L. Sykes, R., Karamchandani, P., Seigneur, C., Lurmann, F., Arndt, R., and Kumar, N.: Second-order Closure Integrated Puff (SCIPUFF) model with gas and aqueous phase chemistry and aerosols, $11^{\text {th }}$ Joint Conference on the Applications of Air Pollution Meteorology with the Air and Waste Management Association, Long Beach, CA, 9-14 January 2000, 10436, 2000. 
Sarwar, G., Godowitch, J., Henderson, B., Fahey, K., Pouliot, G., Hutzell, W. T., Mathur, R., Kang, D., Goliff, W. S., and Stockwell, W. R.: A comparison of atmospheric composition using the Carbon Bond and Regional Atmospheric Chemistry Mechanisms, Atmos. Chem. Phys. Discuss., 13, 6923-6969, doi:10.5194/acpd-13-6923-2013, 2013.

Spicer, C. W., Holdren, M. W., Riggin, R. M., and Lyon, T. F.: Chemical composition and photochemical reactivity of exhaust from aircraft turbine engines, Ann. Geophys., 12, 944-955, doi:10.1007/s00585-994-0944-0, 1994.

Sykes, R. I. and Gabruk, R. S.: A Second-Order Closure Model for the Effect of Averaging Time on Turbulent Plume Dispersion, J. Appl. Meteorol., 36, 1038-1045, doi:10.1175/15200450(1997)036<1038:ASOCMF>2.0.CO;2, 1997.

Sykes, R. I., Parker, S. F., Henn, D. S., Cerasoli, C. P., and Santos, L. P.: PC-SCIPUFF Version 1.1PD.1 Technical Documentation. ARAP Report No. 718. Titan Corporation, Titan Research \& Technology Division, ARAP Group, P.O. Box 2229, Princeton, NJ, USA, 08543-2229, 1998.

Timko, M., Onasch, T., Northway, M., Jayne, J., Canagaratna, M., Herndon, S., Wood, E., and Miake-Lye, R.: Gas Turbine Engine Emissions - Part II: Chemical Properties of Particulate Matter, J. Eng. Gas Turb. Power, 132, 061505-061519, doi:10.1115/1.4000132, 2010.

Tsai, F., Sun, W., and Chen, J.: A Composite Modeling Study of Civil Aircraft Impacts on Ozone and Sulfate over the Taiwan Area, J. Terr. Atmos. Ocean. Sci., 12, 109-135, available at: http://carl.as.ntu.edu.tw/chinese/jpchen/018.pdf, 2001.

Vijayaraghavan, K., Karamchandani, P., Seigneur, C., Balmori, R., and Chen, S.: Plume-in-grid modeling of atmospheric mercury, J. Geophys. Res-Atmos., 113, D24305, doi:10.1029/2008JD010580, 2008.

Wayson, R., Fleming, G., and Iovinelli, R.: Methodology to Estimate Particulate Matter Emissions from Certified Commercial Aircraft Engines, J. Air Waste Manage., 59, 91-100, doi:10.3155/1047-3289.59.1.91, 2009.

Wayson, R. L., Fleming, G. G., and Kim, B.: Status report on proposed methodology to characterize jet/gas turbine engine particulate matter emissions, Federal Aviation Administration, 2003.
Whitt, D., Jacobson, M. Z., Wilkerson, J. T., Naiman, A. D., and Lele, S. K.: Vertical mixing of commercial aviation emissions from cruise altitude to the surface, J. Geophys. Res-Atmos., 116, D14109, doi:10.1029/2010JD015532, 2011.

Wilkerson, J. T., Jacobson, M. Z., Malwitz, A., Balasubramanian, S., Wayson, R., Fleming, G., Naiman, A. D., and Lele, S. K.: Analysis of Emission Data from Global Commercial Aviation: 2004 and 2006, Amos. Chem. Phys., 10, 6391-6408, doi:10.5194/acp-10-6391-2010, 2010.

Wong, H., Yelvington, P., Timko, M., Onasch, T., and MiakeLye, R.: Microphysical Modeling of Ground-Level AircraftEmitted Aerosol Formation: Roles of Sulfur-Containing Species, J. Propul. Power, 24, 590-602, doi:10.2514/1.32293, 2008.

Wood, E., Herndon, S., Timko, M., Yelvington, P., and Miake-Lye, R.: Speciation and chemical evolution of nitrogen oxides in aircraft exhaust near airports, Environ. Sci. Technol., 43, 18841891, doi:10.1021/es072050a, 2008.

Woody, M. and Arunachalam, S.: Secondary Organic Aerosol Produced from Aircraft Emissions at the Atlanta Airport: An Advanced Diagnostic Investigation Using Process Analysis, Atmos. Environ., 76, 101-109, doi:10.1016/j.atmosenv.2013.06.007, 2013.

Woody, M., Baek, B. H., Adelman, Z., Omary, M., Lam, Y. F., West, J., and Arunachalam, S.: An Assessment of Aviation Contribution to Current and Future Fine Particulate Matter in the United States, Atmos. Environ., 45, 3424-3433, doi:10.1016/j.atmosenv.2011.03.041, 2011.

Unal A., Hu Y., Chang M. E., Odman M. T., and Russell A. G.: Airport related emissions and impacts on air quality: Application to the Atlanta International Airport, Atmos. Environ., 39, 57875798, doi:10.1016/j.atmosenv.2005.05.051, 2005.

US EPA: 2002 National Emissions Inventory Data and Documentation, http://www.epa.gov/ttn/chief/net/2002inventory.html (last access: 1 November 2010), 2013a.

US EPA: SPECIATE Version 4.3, http://www.epa.gov/ttn/chief/ software/speciate/index.html (last access: 10 March 2011), 2013 b. 